\title{
Article
}

\section{hiPSC-Derived Schwann Cells Influence Myogenic Differentiation in Neuromuscular Cocultures}

\author{
Sarah Janice Hörner ${ }^{1,2}{ }^{\mathbb{D}}$, Nathalie Couturier ${ }^{1}$, Roman Bruch ${ }^{1} \mathbb{D}$, Philipp Koch ${ }^{3,4,5} \mathbb{D}^{\mathbb{D}}$, Mathias Hafner ${ }^{1,6}$ \\ and Rüdiger Rudolf $1,2,6, *$ (D)
}

1 Institute of Molecular and Cell Biology, Mannheim University of Applied Sciences, 68163 Mannheim, Germany; s.hoerner@hs-mannheim.de (S.J.H.); n.couturier@hs-mannheim.de (N.C.); r.bruch@hs-mannheim.de (R.B.); m.hafner@hs-mannheim.de (M.H.)

2 Interdisciplinary Center for Neurosciences, Heidelberg University, 69120 Heidelberg, Germany

3 Central Institute of Mental Health, Medical Faculty Mannheim of Heidelberg University, 68159 Mannheim, Germany; philipp.koch@zi-mannheim.de

4 Hector Institute for Translational Brain Research (HITBR gGmbH), 68159 Mannheim, Germany

5 German Cancer Research Center (DKFZ), 69120 Heidelberg, Germany

6 Institute of Medical Technology, Mannheim University of Applied Sciences and Heidelberg University, 68163 Mannheim, Germany

* Correspondence: r.rudolf@hs-mannheim.de

check for updates

Citation: Hörner, S.J.; Couturier, N.; Bruch, R.; Koch, P.; Hafner, M.; Rudolf, R. hiPSC-Derived Schwann Cells Influence Myogenic Differentiation in Neuromuscular Cocultures. Cells 2021, 10, 3292. https://doi.org/10.3390/cells10123292

Academic Editor: Andrea Pession

Received: 22 October 2021

Accepted: 21 November 2021

Published: 24 November 2021

Publisher's Note: MDPI stays neutral with regard to jurisdictional claims in published maps and institutional affiliations.

Copyright: (c) 2021 by the authors. Licensee MDPI, Basel, Switzerland. This article is an open access article distributed under the terms and conditions of the Creative Commons Attribution (CC BY) license (https:// creativecommons.org/licenses/by/ $4.0 /)$.

\begin{abstract}
Motoneurons, skeletal muscle fibers, and Schwann cells form synapses, termed neuromuscular junctions (NMJs). These control voluntary body movement and are affected in numerous neuromuscular diseases. Therefore, a variety of NMJ in vitro models have been explored to enable mechanistic and pharmacological studies. So far, selective integration of Schwann cells in these models has been hampered, due to technical limitations. Here we present robust protocols for derivation of Schwann cells from human induced pluripotent stem cells (hiPSC) and their coculture with hiPSC-derived motoneurons and C2C12 muscle cells. Upon differentiation with tuned BMP signaling, Schwann cells expressed marker proteins, S100b, Gap43, vimentin, and myelin protein zero. Furthermore, they displayed typical spindle-shaped morphologies with long processes, which often aligned with motoneuron axons. Inclusion of Schwann cells in coculture experiments with hiPSC-derived motoneurons and C2C12 myoblasts enhanced myotube growth and affected size and number of acetylcholine receptor plaques on myotubes. Altogether, these data argue for the availability of a consistent differentiation protocol for Schwann cells and their amenability for functional integration into neuromuscular in vitro models, fostering future studies of neuromuscular mechanisms and disease.
\end{abstract}

Keywords: AChR; acetylcholine receptors; hiPSC; in vitro; neural crest; neuromuscular junction; NMJ; Schwann cells; stem cells

\section{Introduction}

Neuromuscular junctions (NMJs) are synapses in the peripheral nervous system, where motor signals are transmitted from presynaptic nerve terminals to muscle fibers to induce muscle contraction and, therefore, control body movement. In humans as well as rodents, the core NMJ is a tripartite structure, built of cholinergic lower motoneurons (MN) extending from the spinal cord, nicotinic acetylcholine receptors in the sarcolemma, and specialized Schwann cells (SC), which cap the synapse (Figure 1). To date, a wealth of in vitro NMJ models and studies is available, and recent developments in the areas of microfluidics, 3D cell culture, and human induced pluripotent stem cell (hiPSC) technology have greatly increased their relevance for in vitro assays. Recently, these developments have been reviewed from different angles: Barbeau and colleagues provided a comprehensive overview of historical and recent developments of NMJ cocultures, ranging from first 
animal explant cultures to the latest developments with neuromuscular organoids [1]. Others focused on the potential of NMJ models for synaptogenesis and degeneration studies [2], disease modeling [3], and drug testing [4]. Lynch and colleagues reviewed in vitro models which include at least one cell component derived from human stem cells and emphasized the importance of human-based approaches [5]; Luttrell et al. reviewed state-of-the-art developments of culture formats integrating stem cell-derived in vitro NMJs [6]. Besides all promising developments that have improved the relevance of in vitro NMJ models, their major drawback was a lack of SC, and this was identified as a critical issue. Indeed, terminal SC have been shown to play crucial roles for NMJ development [7-9], maturation [10-12], and function $[13,14]$ in vivo. In vitro, addition of a rat-derived SC line improved maturation in microfluidic neuromuscular cocultures [15]. The higher NMJ maturation levels which can be achieved in explant cultures [16] have been linked to the presence of glia co-differentiating with neurons in explants [17], and primary animal-derived spinal glia were added in neuromuscular cocultures for support of MN [18]. Studies presenting 3D organoids derived from hiPSC-derived neuromuscular cultures, where mixed cell populations were differentiated in parallel, showed the appearance of cells positive for the SC marker S100b [19]. Similar findings were reported from 2D cultures [20]. However, to date, no study has shown selective integration of hiPSC-derived SC into neuromuscular cocultures. This would allow cell type-specific studies and manipulations. Likely a major reason for this flaw is that only few differentiation protocols for stem cell-derived SCs have been available. In addition, most of them are rather time-consuming and offer only low cell yields, thus mostly necessitating cell sorting steps [21-23].

In this study, we present a protocol for setting up tricultures including hiPSC-derived SC combined with hiPSC-derived MN and C2C12 myotubes within nine days. To enable this, we further demonstrate derivation of SC from hiPSC with increased protocol robustness, based on a differentiation protocol presented by Kim and colleagues [24]. This paves the way for studying cell-autonomous processes and how the different cell types influence each other; it opens the possibility to study cell type-specific contributions in pathological scenarios by use of patient-derived hiPSCs, and it might be a further step towards creating more mature in vitro NMJs.

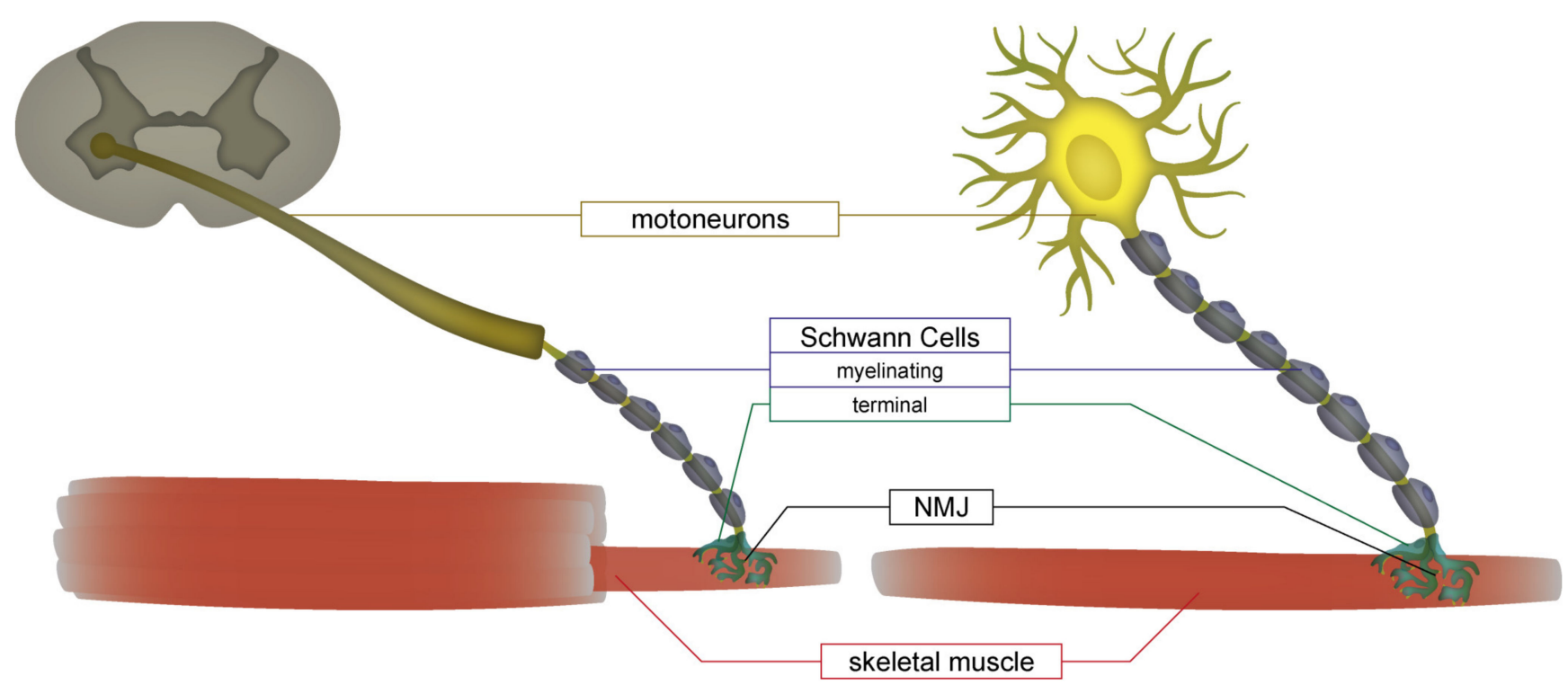

Figure 1. Scheme of the cell components of the core NMJ. Cell bodies of lower motoneurons are located in the ventral horn of the spinal cord (gray structure in the upper left corner), from which their axons extend through spinal nerves to skeletal muscles. Each muscle fiber is innervated at a single synaptic connection, the neuromuscular junction (NMJ). Terminal Schwann cells form an integral part of these synapses; they are different from myelinating Schwann cells, which wrap the axons of motoneurons. For simplicity, further cell types at the NMJ, such as kranocytes and sympathetic neurons, were left out. 


\section{Materials and Methods}

\section{1. hiPSC Culture}

hiPSC cultures were maintained in standard 6-well tissue culture plates coated with heSC-qualified Geltrex (Thermo Fisher Scientific, Darmstadt, Germany) in either E8 or mTeSR1 medium (STEMCELL Technologies, Cologne, Germany), with daily medium changes. hiPSC were split routinely with $0.5 \mathrm{mM}$ EDTA (Thermo Fisher Scientific) upon reaching 80-90\% confluency. Differentiation to motoneurons or Schwann cells was induced 2-3 days after routine EDTA splitting upon 50-60\% confluency of hiPSC colonies by switching to differentiation medium, defining day 0 of differentiation. Throughout differentiation, cells were kept in Geltrex coated 6-well tissue culture plates, and $5 \mu \mathrm{M}$ Y-27632 (STEMCELL Technologies) was added to the medium for no longer than $24 \mathrm{~h}$ after passaging or thawing. For hiPSC differentiation, cell lines 028\#1 (provided by Philipp Koch, HITBR Hector Institute for Translational Brain Research, Mannheim) and WC035i-SOD1-D90D (purchased from WiCell Research Institute, Madison, WI, USA) were used. WC035i-SOD1-D90D was deposited with WiCell by Su-Chun Zhang, University of Wisconsin [25] and is derived from cell line ND29149 from the NINDS Human Genetics Resource Center at the Coriell Institute for Medical Research.

\section{2. hiPSC Motoneuron (MN) Differentiation}

The protocol for MN differentiation was based on Du et al., 2015 [26] and employs molecular factors CHIR99021, for Wnt activation; dual SMAD inhibitors SB431542 and DMH1, for neural induction; retinoic acid, for caudalization; Shh activator purmorphamine, for ventralization; and Notch inhibitor Compound E as well as neurotrophic factors BDNF, GDNF, and IGF-1, for neuronal maturation. hiPSC were switched to MN differentiation medium 1 (MNDM1), comprised of MN basal medium (BM) containing Neurobasal medium and DMEM/F12 medium without HEPES (Thermo Fisher Scientific) in a 1:1 ratio, 1\% Penicillin-Streptomycin (Sigma Aldrich, Taufkirchen, Germany), 1\% GlutaMAX (Thermo Fisher Scientific), $0.5 \times$ NeuroCult SM1 Supplement (STEMCELL Technologies), and $0.5 \times$ N2 Supplement (STEMCELL Technologies) and supplemented with $0.1 \mathrm{mM}$ ascorbic acid (Carl Roth, Karlsruhe, Germany), 3 MM CHIR99021 (Tocris Bioscience, Bristol, UK), $2 \mu \mathrm{M}$ DMH1 (Selleck Chemicals, Houston, TX, USA), and $2 \mu \mathrm{M}$ SB431542 (Cell Guidance Systems, Cambridge, UK). MNDM1 was changed daily for 6 days. As cells became denser, medium volume per well was increased to prevent medium acidification between medium changes. On day 6, cells were passaged using Accutase (Thermo Fisher Scientific) and plated at a 1:6 ratio onto Geltrex coated 6-well plates in MNDM2, consisting of BM supplemented with $0.1 \mathrm{mM}$ ascorbic acid, $1 \mu \mathrm{M}$ CHIR99021, $2 \mu \mathrm{M}$ DMH1, $2 \mu \mathrm{M}$ SB431542, $0.5 \mu \mathrm{M}$ purmorphamine (Cell Guidance Systems), and $0.1 \mu \mathrm{M}$ all-trans retinoic acid (Sigma Aldrich). MNDM2 was changed daily until day 12, when cells were split into suspension culture using Dispase-II (Merck Millipore, Darmstadt, Germany) in 6-well suspension culture plates. Cells were split at a well ratio of 1:2 in 4-5 mL MNDM3 per well, consisting of BM supplemented with $0.1 \mathrm{mM}$ ascorbic acid, $0.1 \mu \mathrm{M}$ purmorphamine, $0.5 \mu \mathrm{M}$ retinoic acid, $10 \mathrm{ng} / \mathrm{mL}$ BDNF, $10 \mathrm{ng} / \mathrm{mL}$ GDNF, and $10 \mathrm{ng} / \mathrm{mL}$ IGF-1 (Peprotech, Hamburg, Germany). Medium was changed every other day by carefully replenishing $75 \%$ of medium volume in each well. After 6 more days, cell aggregates were collected and dissociated into a single cell suspension with Accumax (Sigma Aldrich). Cells were seeded subsequently at a 1:1-1:3 ratio into PLL (Sigma Aldrich)/rhLaminin-521 (BioLamina, Sundbyberg, Sweden)-coated plates in MNDM4, consisting of BM supplemented with $0.1 \mathrm{mM}$ ascorbic acid, $0.1 \mu \mathrm{M}$ purmorphamine, $0.5 \mu \mathrm{M}$ retinoic acid, $0.1 \mu \mathrm{M}$ Compound $\mathrm{E}$ (Merck Millipore), $10 \mathrm{ng} / \mathrm{mL}$ BDNF, $10 \mathrm{ng} / \mathrm{mL}$ GDNF, and $10 \mathrm{ng} / \mathrm{mL}$ IGF-1. After each replating, ROCK1 inhibitor Y-27632 (Cell Guidance Systems) was added to the medium for $24 \mathrm{~h}$ at a concentration of $5 \mu \mathrm{M}$. For expansion and cryopreservation, motoneuron progenitors were either frozen on day 12 in BM containing 10\% DMSO (Carl Roth) and $10 \mu \mathrm{M}$ Y-27632 or expanded with Accutase at a 1:6 ratio every 6 days for 1-2 passages and frozen subsequently. For expansion and thawing, MNDM2 was additionally supplemented 
with $0.5 \mathrm{mM}$ valproic acid (Sigma Aldrich), and after thawing, $10 \mu \mathrm{M}$ Y-27632 was added for $24 \mathrm{~h}$. Throughout the protocol, all media containing retinoic acid were kept away from direct light and stored in light protected containers, and direct light inside the biosafety cabinet was turned off when changing medium.

\section{3. hiPSC Schwann Cell (SC) Differentiation}

SC differentiation protocol was modified from Kim et al., 2017 [24] and employs molecular factors CHIR99021 and SB431542 for Wnt activation and neuralization; BMP activator BMP4 and BMP inhibitor DMH1 to precisely activate BMP signaling; and factors known to drive SC differentiation, which are neuregulin $\beta-1$ (NRG1), adenylyl cyclase activator forskolin, retinoic acid, and PDGF-BB. First, hiPSC were differentiated to SC precursors in 24 days. Basal medium for SC precursor differentiation consisted of Neurobasal medium and Advanced DMEM/F12 (Thermo Fisher Scientific) in a 1:1 ratio, 1\% Pen-Strep, 1\% GlutaMAX, $1 \times$ SM1 supplement, and $1 \times$ N2 supplement. Differentiation was induced on day 0 by switching to SC precursor differentiation medium 1 (SCPM1), supplemented with $2 \mu \mathrm{M}$ SB431542 and $3 \mu \mathrm{M}$ CHIR99021. After 6 days, cells were split 1:10 with Accutase into SCPM2 supplemented with $2 \mu$ M SB431542, $3 \mu$ M CHIR99021, 50 ng/mL NRG1, 15 ng/mL BMP4, and $1 \mu \mathrm{M}$ DMH1. On day 12, cells were split 1:6 into SCPM3 supplemented with $2 \mu \mathrm{M}$ SB431542, $3 \mu \mathrm{M}$ CHIR99021, and $50 \mathrm{ng} / \mathrm{mL}$ NRG1. Cells were maintained in SCPM3 until day 24 , with another split on day 18 . Then, base medium was switched to SC medium (SCM), consisting of DMEM/low glucose (Thermo Fisher Scientific) supplemented with 1\% Pen-Strep, 1\% GlutaMAX, 1\% FBS, and $200 \mathrm{ng} / \mathrm{mL}$ NRG1. On day 24, SC precursors were split 1:3-1:6 in SCM additionally supplemented with $4 \mu \mathrm{M}$ forskolin, $0.1 \mu \mathrm{M}$ alltrans retinoic acid, and $10 \mathrm{ng} / \mathrm{mL}$ PDGF-BB. On day 28, SCM was supplemented with PDGF-BB but not with forskolin or retinoic acid anymore. From day 30 onwards, cells were maintained in SCM without PDGF-BB, forskolin, or retinoic acid. SC were allowed to grow to confluency and then passaged with Accutase at a 1:3 ratio. Keeping the cultures above $40 \%$ confluency increased cell survival. Cells were maintained up to day 100 and cryopreserved upon routine splitting. SC used for experiments were between days 50 and 90 of differentiation.

\section{4. $\mathrm{C} 2 \mathrm{C} 12$ Culture}

C2C12 murine myoblasts were maintained in C2C12 growth medium (GM) consisting of DMEM/F12, high glucose, and L-glutamine, without sodium pyruvate (Sigma Aldrich) and supplemented with 20\% FBS (Capricorn Scientific, Ebsdorfergrund, Germany). Cells were passaged every other day using trypsin (Sigma Aldrich) and were never allowed to grow beyond $60 \%$ confluency. Differentiation to myotubes was induced by switching confluent cultures to $\mathrm{C} 2 \mathrm{C} 12$ differentiation medium (DM) supplemented with $2 \%$ horse serum (Thermo Fisher Scientific). Generally, only C2C12 below passage 20 were used. We noticed an influence of C2C12 passage specifically on acetylcholine receptor (AChR) cluster formation and, therefore, recommend using $\mathrm{C} 2 \mathrm{C} 12$ of the same passage number for experiments which are to be compared. Data used for AChR cluster analysis were obtained from experiments using $\mathrm{C} 2 \mathrm{C} 12$ at passage 12 at the timepoint of differentiation induction.

\subsection{Tricultures}

To obtain tricultures, cryopreserved C2C12 myoblasts, MN progenitors, and SC were thawed on the same day. C2C12 were routinely passaged and, two days prior to triculture seeding, plated in GM at a density of 70,000-80,000 cells per $\mathrm{cm}^{2}$ into Geltrex coated 6-well tissue culture plates with glass coverslips placed in the wells and switched to DM the following day. SC were cultured in SCM and passaged once with Accutase 4-5 days after thawing, depending on confluency. MN progenitors were grown for 3 days after thawing in MNDM2 containing valproic acid to obtain a dense cell layer and then split to suspension, as described for MN differentiation. Six days later, MN aggregates were dissociated with Accumax, and SC were detached using Accutase. MN and SC were then plated at a 1:1 
well ratio onto $\mathrm{C} 2 \mathrm{C} 12$, either individually for cocultures or combined for tricultures. Cells were plated in triculture medium (triM) consisting of $\mathrm{MN}$ basal medium supplemented with $0.1 \mathrm{mM}$ ascorbic acid, $0.1 \mu \mathrm{M}$ purmorphamine, $0.5 \mu \mathrm{M}$ retinoic acid, $10 \mathrm{ng} / \mathrm{mL} \mathrm{BDNF}$, $10 \mathrm{ng} / \mathrm{mL}$ GDNF, $10 \mathrm{ng} / \mathrm{mL}$ IGF-1, and $200 \mathrm{ng} / \mathrm{mL}$ NRG1. Next, $10 \mu \mathrm{M}$ Y-27632 was added upon seeding, and $24 \mathrm{~h}$ later, medium was changed to triM without Y-27632. At all following medium changes, only half the volume of medium per well was changed in order to cause minimal disturbance to cells.

\subsection{Immunofluorescence Staining and Microscopy}

Cultures were fixed with 4\% PFA for $15 \mathrm{~min}$, washed in PBS $3 \mathrm{x}$, and either stored at $4{ }^{\circ} \mathrm{C}$ until staining or stained immediately. For stainings of SC including SOX10, cells were permeabilized with $0.1 \%$ Triton X-100 for $3 \mathrm{~min}$ and then incubated for $1 \mathrm{~h}$ at RT in blocking buffer (2\% BSA in PBS). BSA blocking buffer was used subsequently for washes and antibody incubations. For all other stainings, cultures were first incubated for $10 \mathrm{~min}$ at RT in a blocking buffer containing $0.1 \%$ saponin and $0.2 \%$ fish skin gelatin in PBS, which was also used for washes. Antibodies were incubated in $0.01 \%$ saponin $/ 0.2 \%$ gelatin in PBS. For both protocols, primary antibodies were incubated for $1 \mathrm{~h}$ at RT, and secondary antibodies were incubated for $45 \mathrm{~min}$ at RT in the dark. AChR were labelled with $\alpha$-bungarotoxin $(\alpha \mathrm{BTX})$ Alexa Fluor 647 conjugate (Thermo Fisher Scientific) incubated together with secondary antibodies. For a list of all primary antibodies used, see Supplementary Table S1. Imaging for differentiation marker analysis in SC was done using a Leica Aperio Versa Slide Scanner (Leica Biosystems, Wetzlar, Germany) with HC PL FLUOTAR 20×/0.55 DRY objective and DAPI, Cy5, and Spectrum Green filters. All other imaging was performed using an inverted Leica TCS SP8 confocal microscope (Leica Microsystems, Wetzlar, Germany) with HC PL APO 20×/0.75 IMM CORR CS2 objective and 405 nm, 488 nm, $561 \mathrm{~nm}$, and $633 \mathrm{~nm}$ lasers and Leica Application Suite X software. For myotube morphology analysis, image data obtained with both platforms were used. To collect data from most of the culture area while excluding coverslip edges, a $7.5 \times 7.5 \mathrm{~mm}^{2}$ square region central on $\varnothing 12 \mathrm{~mm}$ glass coverslips was imaged for each condition. For stainings designated for quantitative AChR analysis, single optical planes determined by autofocus in the $\alpha$ BTX staining channel were imaged at random regions on the coverslip.

\subsection{Image Segmentation and Quantitative Analysis}

Quantification of marker proteins stained in MN and SC differentiations was performed by detection of cell nuclei (visualized with DAPI) and subsequent measurement of signal intensity in this region for the stained marker in a second channel. For quantification of nuclear stainings of SOX10 and Ki67, detection of nuclei was performed using the BeadNet software [27]. A manually labeled dataset of 31 images $\left(128 \times 128 \mathrm{px}^{2}\right)$ was created for training and testing the algorithm. The detected nuclei center points were then used to determine whether the cell was positive or negative for the analyzed staining. To achieve this, the marker staining image was smoothed by a Gaussian filter with sigma $=0.5$. Then, the maximum value inside a $3 \times 3 \mathrm{px}^{2}$ region, centered at the detected nuclei location, was calculated and compared to a user-defined threshold. A maximum value greater than the threshold was counted as a positive cell; otherwise, the cell was counted as negative. For quantification of S100b and P0, the individual nuclei were segmented using the TWANG algorithm [28] implemented in XPIWIT [29], and mean intensity values obtained from the marker staining channel within the segmented nuclear area were compared to a user-defined threshold to determine positive cells.

To give an indication of how many elongated bipolar cells were present and how pronounced their structure was, the elongation index was introduced. This measure provides information about the summed length of narrow structures. To calculate this value, images of SC cultures stained for S100b were smoothened by a Gaussian filter with sigma $=8$ and segmented using a user-defined threshold. Subsequently, narrow structures were removed from the segmented image by performing 8 iterations of binary erosion 
followed by 8 iterations of binary dilation with a $3 \times 3 \mathrm{px}^{2}$ diamond-shaped structure element. To calculate the difference between the processed and raw segmentation, an element-wise XOR operation was performed. The resulting segmentation showed mainly narrow structures. To remove artifacts, objects with an area smaller than $960 \mathrm{px}^{2}$, an eccentricity smaller than 0.75 , or a major axis length smaller than 120 px were deleted. Finally, the elongation index was calculated by adding up the major axis lengths of the remaining objects and dividing it by the number of positive cells. Cell classification and calculation of the elongation index were performed in Python.

In tricultures, quantification of SC alignment, as well as AChR cluster colocalization, was performed by manual counting and classification using confocal image stacks. For myotube area analysis, images were analyzed using labels allowing the visualization of myotubes (i.e., MF20, desmin, or $\alpha$ BTX). Myotubes were manually outlined and their individual areas obtained using the Fiji distribution of ImageJ [30]. Data were then processed in R (see Statistical Analysis). For AChR cluster segmentation, confocal single plane images were checked manually, and images with obvious detachment of myotubes were excluded. Image analysis was done in Fiji with a custom macro to semi-automate the process. For each experimental condition, a coverslip area of at least $25 \mathrm{~mm}^{2}$ was analyzed. Fluorescent clusters were segmented by thresholding and manual selection. For each segmented cluster, area and mean intensity were measured. Subsequently, whole myotubes were visualized by increasing image contrast and segmented, and the area was measured for normalization of cluster number.

\subsection{Statistical Analysis}

Results are presented as mean \pm SD. Statistical analysis was performed using the software GraphPad Prism 8. At least 3 independent experiments were analyzed for each parameter. Data were tested for normal distribution by the Kolmogorov-Smirnov test. If not stated otherwise in the following, results were analyzed using one-way ANOVA with Tukey's multiple comparisons test. Comparison of SOX10+ cells shown in Figure 3 was performed with paired t-tests. Statistical analyses shown in Figure 6 were performed in $\mathrm{R}$, version 4.0.5 (R Core Team, 2021). The dplyr package [31] was used for data manipulation; figures were produced using the packages ggplot2 [32] and scales [33]. In addition, lme4 [34] was used to produce a linear mixed-effect model. Furthermore, $p$-values less than 0.05 were considered significant and reported as ${ }^{*} p<0.05$, ${ }^{* *} p<0.01,{ }^{* * *} p<0.001$. Figures were prepared in Adobe Illustrator CC 2018.

\section{Results}

\subsection{Differentiation of Motoneurons (MN) and Schwann Cells (SC) from hiPSC}

For differentiation of MN from hiPSC, a small molecule differentiation protocol described by Du and colleagues [26,35] was employed with slight modifications (see Methods section). Images of differentiation stages and the sequence of molecular factors are shown in Figure 2A. Briefly, hiPSC were induced to neuroepithelium for six days by dual SMAD inhibition and WNT activation followed by caudal and ventral patterning with retinoic acid and the Sonic hedgehog activator purmorphamine. After 12 days, $\mathrm{MN}$ precursors positive for Olig2 (71.5 $\pm 11.4 \%$ of total cells, mean \pm SD) were obtained (Figure $2 B, C)$. These could be expanded and cryopreserved. From day 12 on, precursors were cultured in suspension with added neurotrophic factors for six days and then seeded adherently again for final maturation. MN obtained after 20-30 days of differentiation were positive for vesicular acetylcholine transporter (vAChT; $93.0 \pm 2.9 \%$ of total cells), as shown in Figure $2 \mathrm{~B}, \mathrm{C}$. $\mathrm{MN}$ could be cultured and further matured up to day 50 and were furthermore confirmed by immunostaining to express $\beta$ III-tubulin (Tubb3), $\mathrm{Hb} 9$, Isl1, choline acetyltransferase (ChAT), Map2, tau, peripherin (Prph), and synaptophysin (Sph); representative images are shown in Figure 2D and Supplementary Figure S1. 


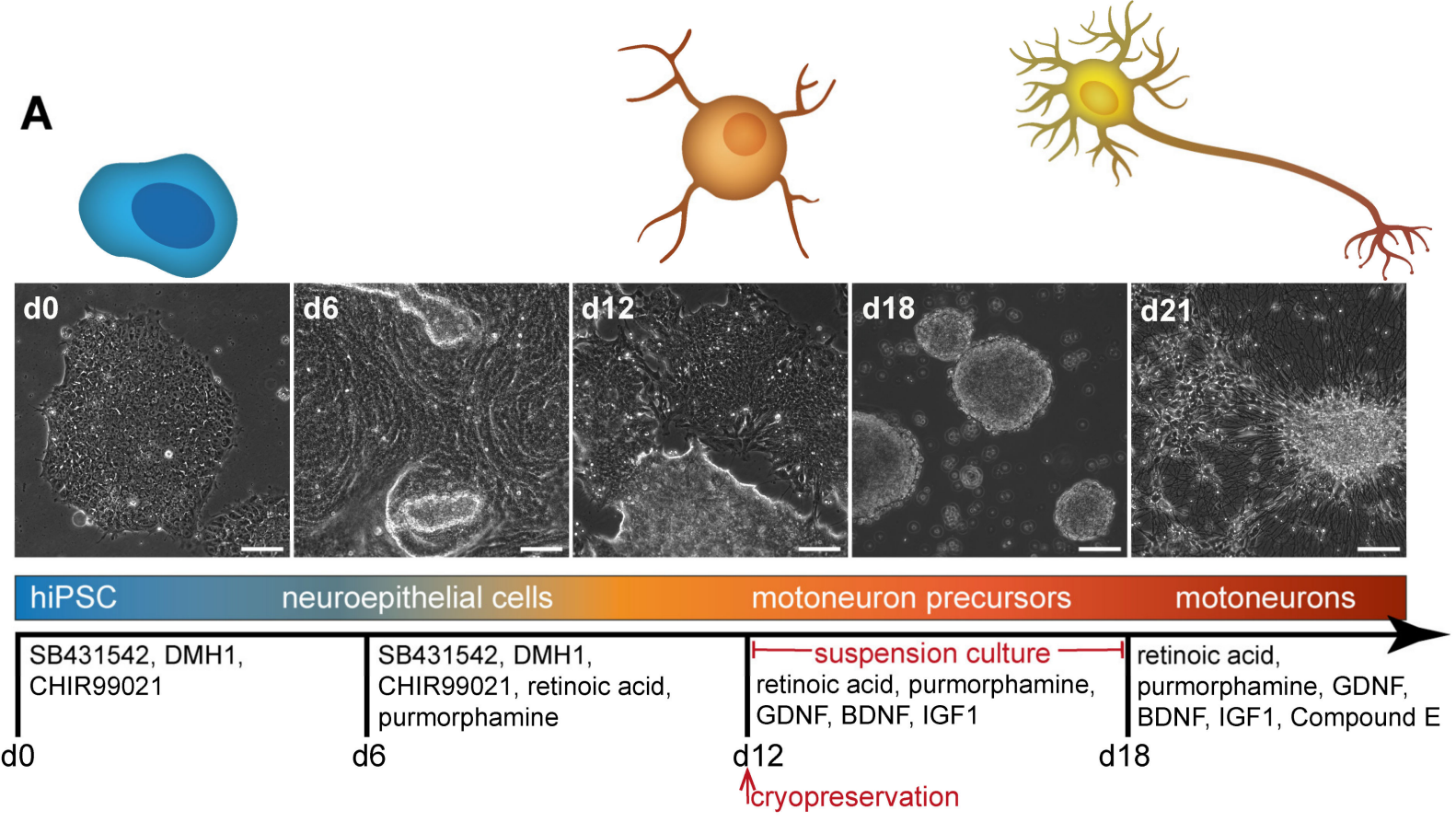

B DAPI Olig2

DAPI

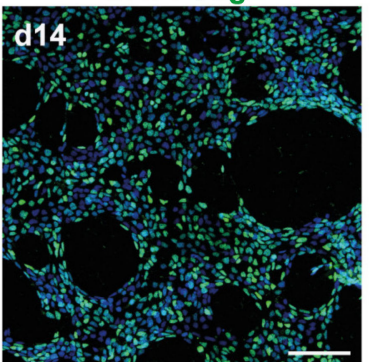

DAPI vAChT Tubb3
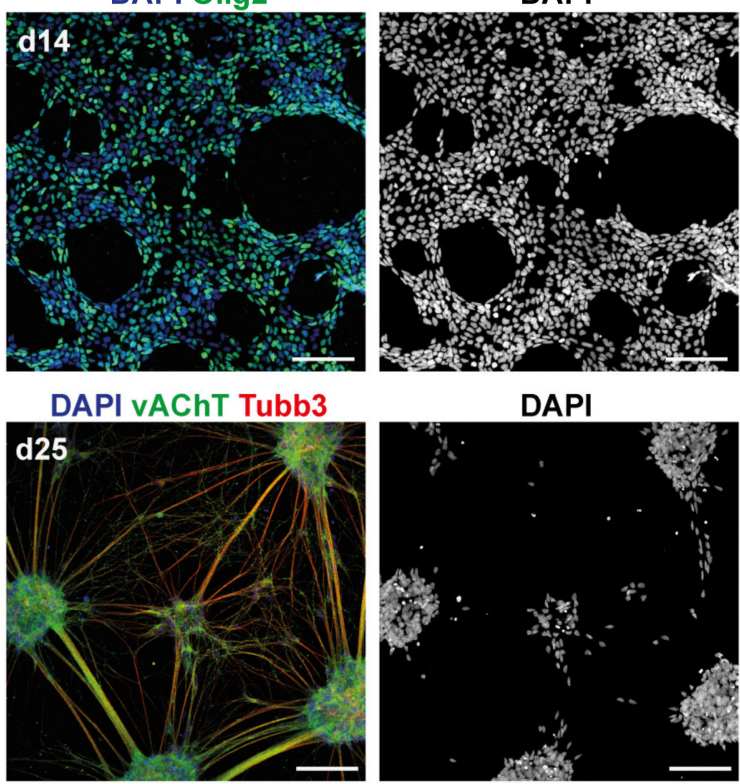

DAPI
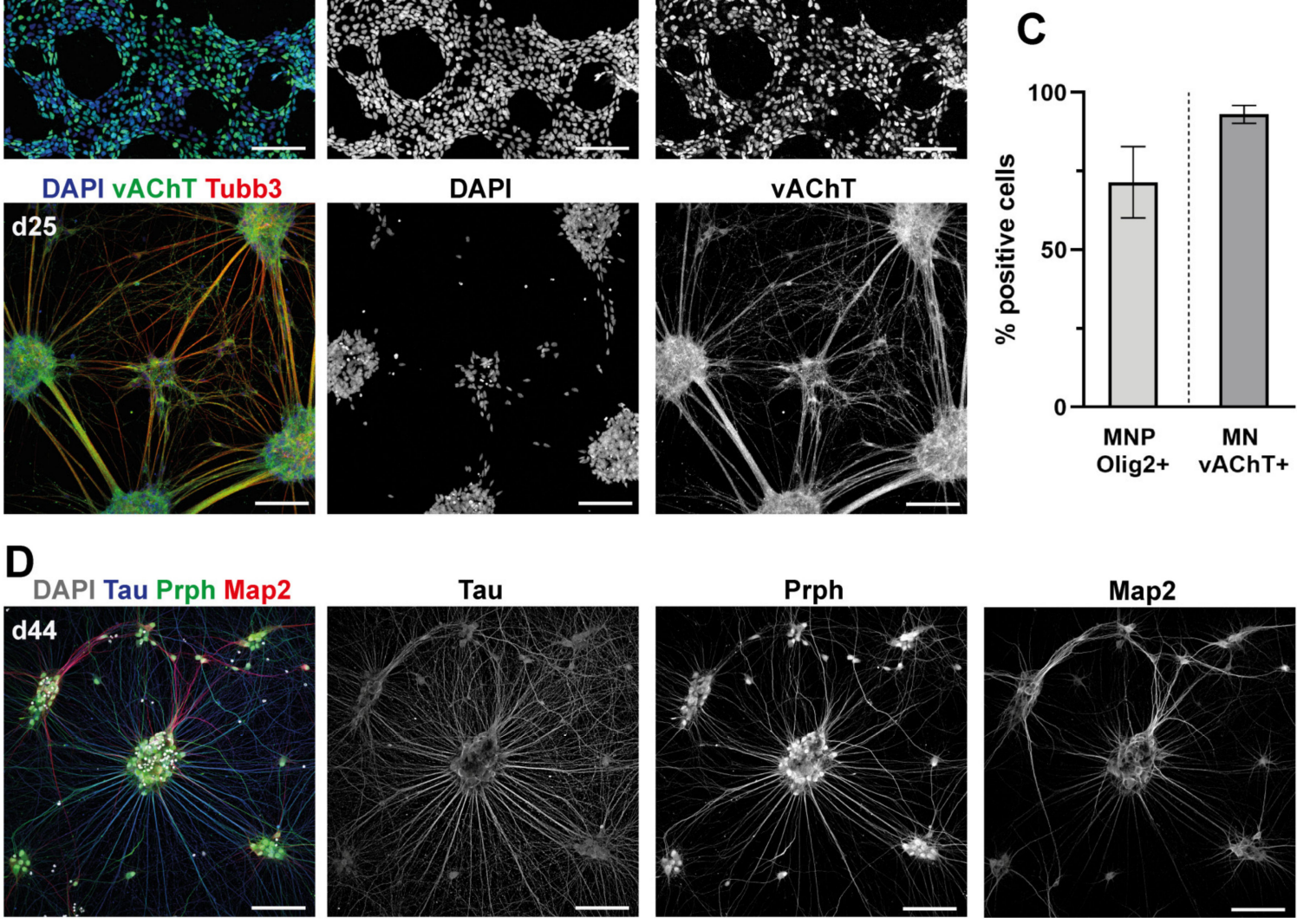

Figure 2. Morphological characteristics and marker protein expression indicate differentiation of motoneurons from hiPSC. (A) Schematic representation of protocol timeline and differentiation factors used. Micrographs show representative brightfield images of cell populations at differentiation times as indicated on the top left of images. MN precursors (MNP) 
could be cryopreserved after 12 days; MN were obtained after 20-30 days of differentiation. Scale bars: $100 \mu \mathrm{m}$. (B-D) hiPSC were differentiated according to the protocol shown in A, fixed at time points as indicated on the top left of panels, and then immunostained for markers as displayed above the panels. Nuclei were labeled with DAPI. (B) Representative micrographs with fluorescence signals for Olig2 in MNP (upper panels) and vesicular acetylcholine transporter (vAChT)/ $\beta$ III-tubulin (Tubb3) in MN (lower panels). Color codes in merge images as indicated. Scale bars: $100 \mu \mathrm{m}$. (C) Quantification of Olig2+ and vAChT + cells at d14 ( $n=5$ experiments) and d25 ( $n=4$ experiments), respectively. All data were normalized to total cell count. Graph depicts mean \pm SD. (D) Mature hiPSC-derived MN stained for Tau, Map2, and Peripherin (Prph). Color code in merge image as indicated. Scale bars: $100 \mu \mathrm{m}$.

Differentiation of SC was based on a protocol by Kim and colleagues [24] which yielded SC precursor cells within 24 days (Figure 3A). Accordingly, cells were neuralized by activin inhibition and WNT activation but without inhibiting BMP. From day 6 on, neuregulin-1 (NRG1) was added to the medium to induce neural crest differentiation towards SC fate. To further promote neural crest specification, we additionally included BMP4 and the BMP inhibitor DMH1 from days 6 to 12. This aspect was not part of the original protocol from Kim et al. and is described in more detail in Section 3.2. Subsequently, SC precursors were obtained after 24 days and differentiated to immature SC through increased concentration of NRG1 and added factors PDGF-BB, forskolin, and retinoic acid. From day 30 onwards, SC were cultured in their final differentiation medium containing NRG1 and FBS and then expanded and cryopreserved.

\subsection{Tuning of BMP Activation Improves Robustness of Schwann Cell Differentiation}

While SC positive for S100b could be generated with the protocol described above, differentiation success and yield across differentiation batches were both quite variable. Thus, as suggested recently by Hackland and colleagues [36], we tested whether precise intermediate activation of BMP signaling by using a small molecule top-down inhibition system was able to increase protocol robustness with respect to promoting neural crest cell derivation. To this end, a saturating concentration of exogenous BMP4 was applied, while at the same time, BMP signaling was attenuated using the BMP inhibitor DMH1 to achieve optimal BMP activity independent from fluctuations in endogenous BMP levels. Based on the work of Hackland et al., we used the same concentrations of BMP4 and DMH1 and a similar treatment time, which started following the first six days of neuralization at the same time as NRG1 was added to induce specification of neural crest cells. After 12,19 , and 26 days of differentiation, the cultures were screened for the presence of the neural crest marker SOX10 (Figure 3B). At all timepoints evaluated, the mean proportion of SOX10+ cells increased significantly upon activation of BMP signaling; in addition, yields of SOX10+ cells were much more consistent between different experiments with tuned BMP as compared to cells not treated with BMP4 and DMH1 (Figure 3C; percentage of SOX10+ cells increased from $21.0 \pm 23.5 \%$ to $62.6 \pm 14.1 \%$ at day 12 , from $46.6 \pm 28.4 \%$ to $90.2 \pm 10.0 \%$ at day 19 , and from $45.1 \pm 30.3 \%$ to $77.0 \pm 11.3 \%$ at day 26 ; mean \pm SD). Confirming earlier reports [36], the beneficial effect of BMP4 addition was only observed if the BMP antagonist DMH1 was applied simultaneously (Figure S2A). SOX10+ cells derived with this modified protocol were successfully differentiated further into SC positive for SC markers, myelin protein zero (P0) and S100b (Figure 3D). Furthermore, we tested whether the protocol could work in completely defined conditions, i.e., by replacing the ill-defined biologicals, BSA and FBS, with specific molecular components. This showed that addition of FBS from day 24 onwards was necessary for a sufficient yield of Schwann cells. In serum-free conditions, Schwann cells were able to differentiate but at low survival and efficiency $(18.7 \pm 5.7 \%$ SOX10+ cells, $20.6 \pm 6.3 \%$ positive for S100b at day 38; Figure S2B). However, BSA and $\beta$-mercaptoethanol were dispensable during SC precursor differentiation, regardless of whether BMP4 and DMH1 were added or not (Figure S2C). 

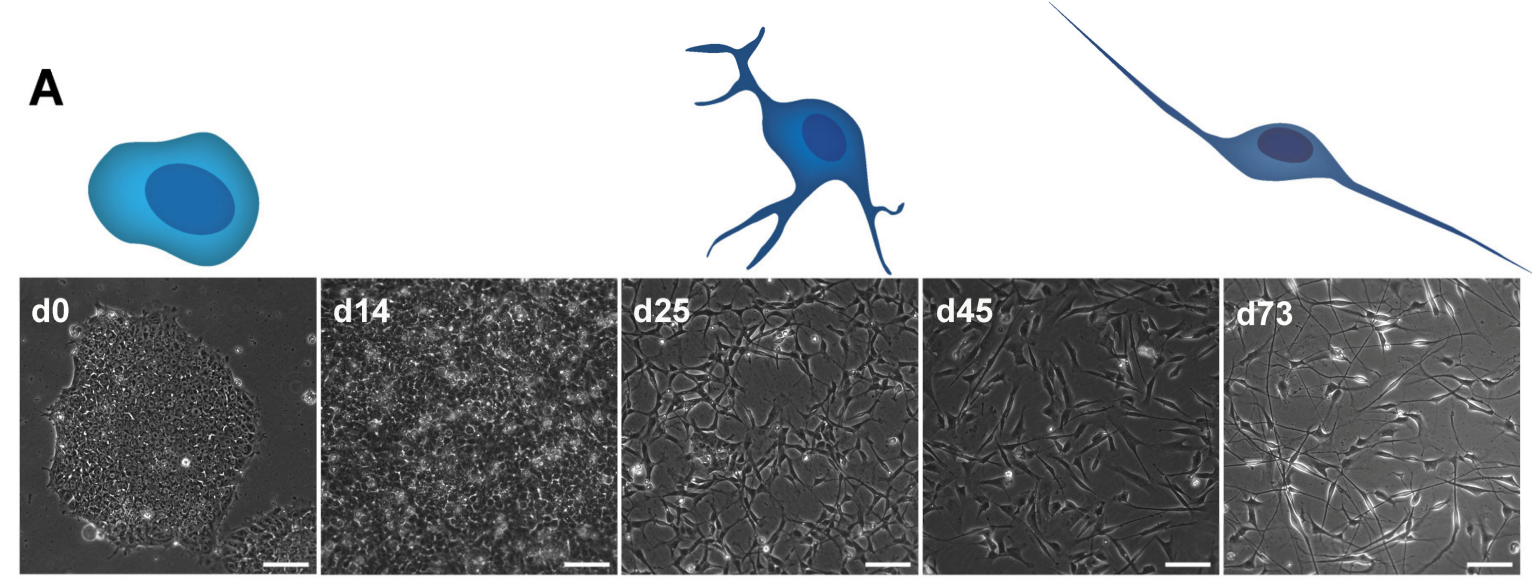

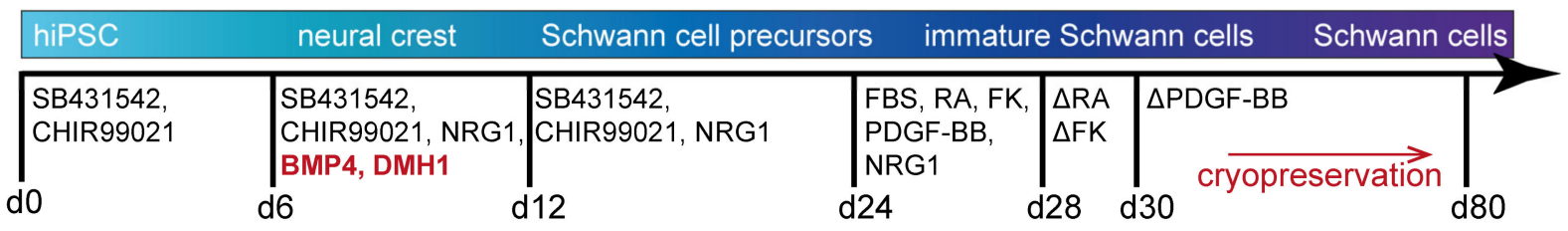

\section{B}

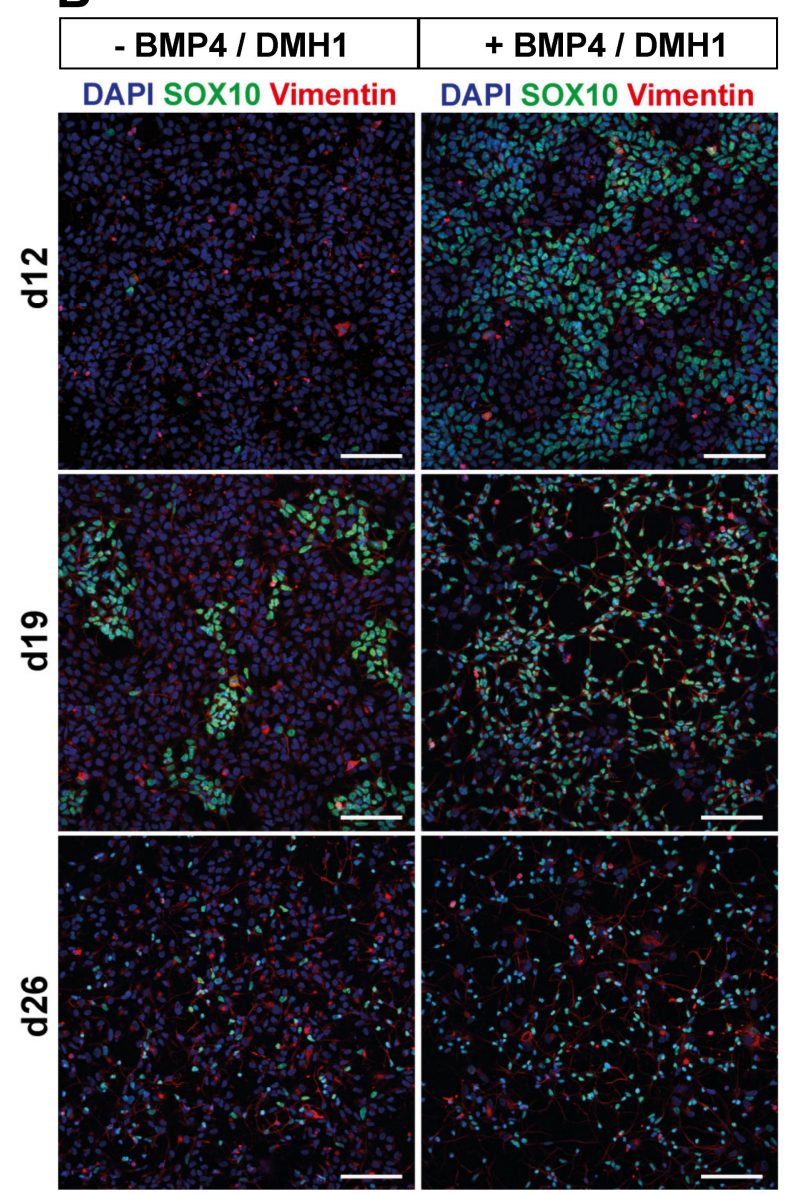

C

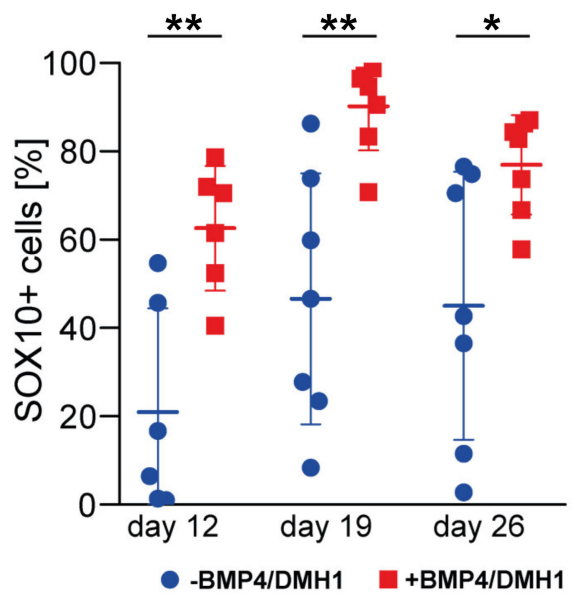

D

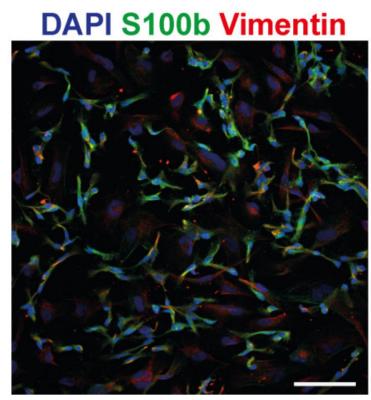

DAPI PO F-Actin

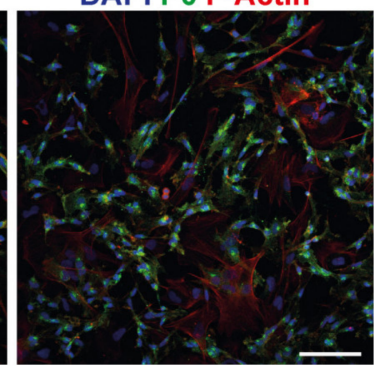

Figure 3. Robustness of Schwann cell differentiation is increased by defined activation of BMP signaling. (A) Schematic representation of protocol timeline and differentiation factors used. Micrographs show representative brightfield images of cell populations at differentiation times as indicated on the top left of each image. SC were obtained after 30-40 days of differentiation but could be cultured and further matured until at least day 100; cryopreservation could be performed at every passage. Scale bars: $100 \mu \mathrm{m}$. (B-D) hiPSC were differentiated according to the protocol shown in A. Control of BMP signaling was either applied (+ BMP4/DMH1) or left out (- BMP4/DMH1). Samples were fixed at time points as indicated 
and then immunostained for markers as displayed on top of panels. Nuclei were labeled with DAPI. (B) Representative micrographs showing fluorescence signals for SOX10 and Vimentin under conditions as indicated. Color code: see top of panel. Scale bars: $100 \mu \mathrm{m}$. (C) Quantification of SOX10+ cells under conditions and at time points as indicated. Graph depicts mean $\pm \mathrm{SD}(\mathrm{n}=6$ experiments for day $12 ; \mathrm{n}=7$ experiments for day 19 and day 26$) .{ }^{*} p<0.05,{ }^{* *} p<0.01$. (D) Representative micrographs of cells differentiated in the presence of BMP4 and DMH1 showing fluorescence signals for SC markers, S100b or myelin protein zero (P0), as well as Vimentin or F-actin at day 32. Color code: see top of panel. Scale bars: $100 \mu \mathrm{m}$.

\subsection{Differentiation of hiPSC-Derived Schwann Cells Is Promoted in Triculture Medium}

In preparation for triculture establishment, we tested whether differentiated SC were supported in a medium formulation designed for tricultures based on MN differentiation medium. For simplicity, we refer to this medium as "triculture medium" (triM). To support the different cell types in tricultures, triM contained differentiation and maturation factors NRG1, retinoic acid (RA), purmorphamine (Pur), ascorbic acid (AA), BDNF, GDNF, and IGF-1. After switching hiPSC-SC monocultures to triM, we observed a rapid change in cell morphology towards a bipolar elongated spindle shape, as would be expected for well-differentiated SC (Figure 4A). To identify individual molecular factors affecting these morphological changes, cells were cultured in either standard SC medium (SCM), fully supplemented triculture medium (triM), triculture base medium (BM), BM supplemented with NRG1 only, BM supplemented with NRG1, RA, and Pur, or BM supplemented with NRG1, RA, and AA. After three days of culture, cells were fixed and immunostained for differentiation and maturation markers (Figure 4A; Figure S3 shows all conditions). The percentage of cells positive for Ki67, P0, and S100b, respectively, was quantified by image segmentation (Figure 4B-D). After three days in triM, a drop of Ki67+ cells to $18.1 \pm 5.9 \%$ (mean $\pm \mathrm{SD}$ ), compared to $38.0 \pm 6.3 \%$ in SCM, indicated a decreased proliferation in triM. Under the same condition, expression of SC markers increased, i.e., from $53.6 \pm 15.1 \%$ in SCM to $83.4 \pm 11.1 \%$ in triM of cells positive for S100b and from $27.1 \pm 17.9 \%$ in SCM to $80.9 \pm 13.4 \%$ in triM of cells positive for P0. Conversely, BM for three days led to no significant changes $(21.8 \pm 7.9 \% \mathrm{Ki} 67+; 63.7 \pm 12.6 \% \mathrm{~S} 100 \mathrm{~b}+$; and $56.0 \pm 13.5 \% \mathrm{P} 0+)$ and nor did BM supplemented with NRG1 only $(23.5 \pm 14.8 \% \mathrm{Ki} 67+; 69.5 \pm 16.3 \% \mathrm{~S} 100 \mathrm{~b}+$; and $55.6 \pm 6.7 \% \mathrm{P} 0+$ ). In contrast, upon supplementation of BM with NRG1, RA, and Pur, the percentage of Ki67+ cells was reduced significantly to $15.0 \pm 10.9 \%$, and that of $\mathrm{P} 0+$ cells significantly increased to $82.9 \pm 6.4 \%$, while the proportion of $\mathrm{S} 100 \mathrm{~b}+$ cells showed an upward trend which was not significant $(78.4 \pm 14.6 \%)$. Similarly, in BM supplemented with NRG1, RA, and AA, Ki67+ cells decreased to $15.1 \pm 9.2 \%$, and S100b+ and $\mathrm{P} 0+$ cells increased to $88.6 \pm 6.6 \%$ and $82.9 \pm 9.1 \%$, respectively. In summary, these data suggested that RA and Pur/AA synergistically reduced proliferation and enhanced $\mathrm{SC}$ marker expression during the SC maturation period.

To further consolidate this finding, we determined the occurrence of spindle-shaped cell morphologies as a proxy for SC maturation. To this end, a segmentation analysis pipeline was developed which yielded a numerical value termed "elongation index". This positively correlated with the presence of thin, elongated cellular processes. Therefore, fluorescence images of cell cultures stained for $\mathrm{S100b}$ were first segmented by manual thresholding. Subsequently, all narrow structures were removed from the segmented image by erosion and dilation operations (for detailed description, see Methods section). By subtracting the resulting images from the originally segmented images, only narrow structures remained (Figure 4E). For each condition, the major axis lengths of these structures were added up and divided by the respective number of S100b+ cells to obtain the elongation index (Figure 4F). For cells cultured for three days in either SCM or triM, this method retrieved elongation indices of $5.3 \pm 5.0$ and $23.9 \pm 9.3$, respectively (Figure 4F). Consistently, while no significant changes of elongation index were observed for BM and $\mathrm{BM}+\mathrm{NRG} 1$ cultures $(8.6 \pm 6.1$ and $6.7 \pm 4.5$, respectively), BM + NRG1 + RA + Pur (19.3 \pm 7.0) and, even more pronounced, BM + NRG1 + RA + AA (31.2 \pm 9.7$)$ led to clearly enhanced elongation. In conclusion, differentiation of hiPSC-derived SC was promoted in 
triM, as illustrated by an increase in S100b- and P0-positive cells, a decrease in proliferation, and morphological changes towards a more elongated cell shape; according to our data, RA and AA were major drivers of these improvements.
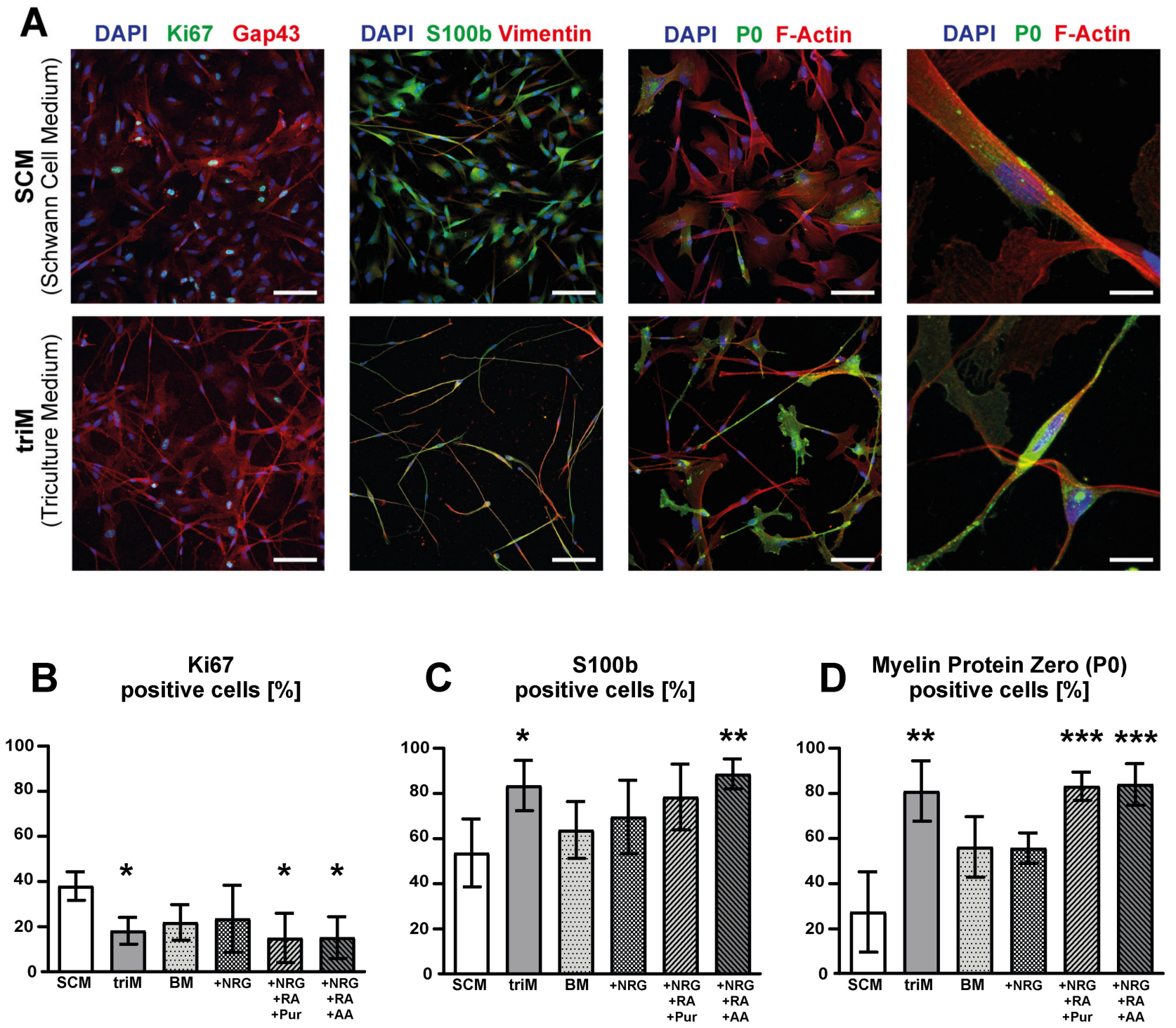

E

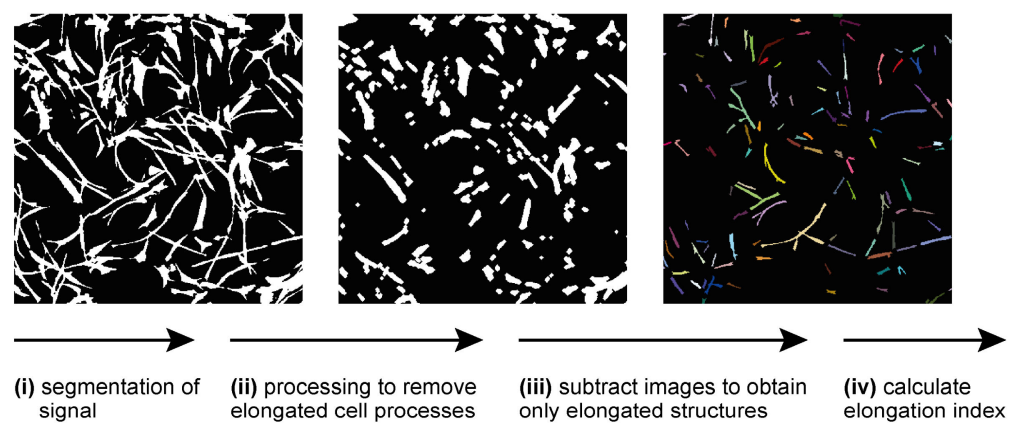

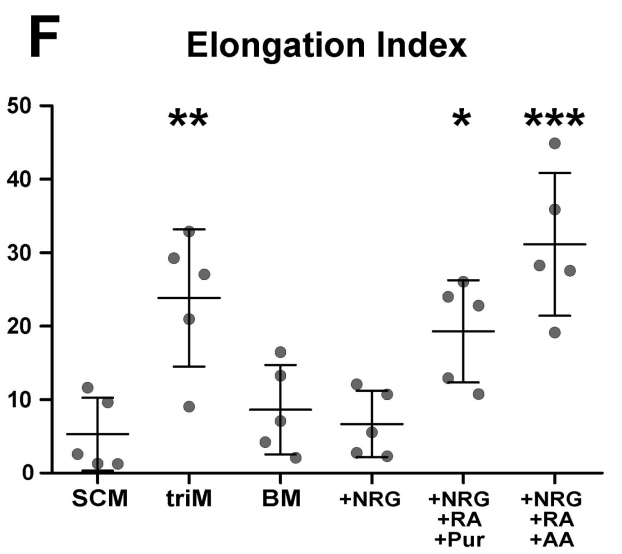

Figure 4. Triculture medium promotes differentiation of hiPSC-derived Schwann cells. SC differentiated from hiPSC using the SC differentiation protocol, including BMP4 tuning, were cultured for three days in either standard SC medium (SCM), 
fully supplemented triM, triculture basal medium (BM), or BM with supplementation of different factors (indicated by "+"). Then, cells were fixed and stained for different marker proteins and imaged using fluorescence microscopy. (A) Representative micrographs of cells stained for Ki67, Gap43, S100b, Vimentin, P0, and F-actin (color codes indicated on top of each panel); examples shown for SCM and triM conditions. Scale bars: $100 \mu \mathrm{m}$; zoom images in fourth column: $20 \mu \mathrm{m}$. (B-D) Quantification of cells positive for Ki67 (B), S100b (C), and P0 (D) for all conditions. Mean \pm SD ( $\mathrm{n}=5$ for Ki67 and $\mathrm{S100b}, \mathrm{n}=3$ for P0). (E) Illustration of image processing workflow to calculate the elongation index. (F) Comparison of elongation index values obtained for all conditions. All values presented as mean $\pm \operatorname{SD}(\mathrm{n}=5) .{ }^{*} p<0.05,{ }^{* *} p<0.01$, *** $p<0.001$.

\subsection{Tricultures Including hiPSC-Derived SC Can Be Prepared from Frozen Cells in Nine Days}

As mentioned, triM was based on the final MN differentiation medium, but Compound E was replaced with NRG1 to support SC. When used instead of standard C2C12 differentiation medium (DM), the serum-free triM formulation was able to induce differentiation of $\mathrm{C} 2 \mathrm{C} 12$ into myotubes which showed spontaneous contractions. However, compared to DM, differentiation seemed to progress more rapidly in triM, and already after few days, extensive cell detachment and cell death was observed. This effect could be prevented if differentiation was induced initially by culturing C2C12 in DM and switching to triM subsequently. Therefore, in order to create tricultures $\mathrm{C} 2 \mathrm{C} 12$ cells were seeded first and left for $24 \mathrm{~h}$ in differentiation medium. Then, hiPSC-derived SC and MN were added and the cultures switched to triM. This way, starting from cryopreserved $\mathrm{C} 2 \mathrm{C} 12$ myoblasts, MN precursors, and SC, tricultures were obtained in nine days (Figure 5A). All three cell types were thawed on the same day in their respective media. C2C12 and SC were regularly passaged until tricultures were established. MN precursors were grown to a dense cell layer and subsequently cultured in suspension for six days. Two days prior to triculture seeding, $\mathrm{C} 2 \mathrm{C} 12$ myoblasts were plated and differentiation to myotubes was induced $24 \mathrm{~h}$ later by switching to myoblast differentiation medium. Another $24 \mathrm{~h}$ later, the neurospheres obtained during the suspension phase were dissociated into a single-cell suspension and added to muscle cultures together with SC. Cultures usually developed within a few days to show contracting myotubes. Before massive contraction-induced detachment of the cultures from the glass surface, tricultures were fixed for evaluation three days after seeding of neurons and SC. Subsequently, staining for specific marker proteins was performed. These included Tubb3, synaptophysin, and vAChT for MN; S100b and vimentin for SC; and, finally, desmin or myosin heavy chain for myotubes. Additionally, nicotinic acetylcholine receptors (AChR), a marker for NMJs, were labelled with the snake venom $\alpha$-bungarotoxin $(\alpha \mathrm{BTX})$ coupled to a fluorescent dye. Frequently, an alignment of SC with neurites was seen $(79.9 \pm 8.3 \%$ of $S C$ in tricultures were completely or partially aligned with neurons; mean $\pm S D, n=4$ ) as well as colocalization of AChR with $\mathrm{MN}(70.0 \pm 6.6 \%$ of all $\mathrm{AChR}$ clusters in tricultures colocalized with $\mathrm{MN})$ or with both $\mathrm{MN}$ and SC $(17.6 \pm 10.1 \%$ of all AChR clusters; mean \pm SD, $\mathrm{n}=4)$. Representative confocal microscopy images of tricultures are shown in Figure 5B and Figure S4. To test whether the protocol could potentially be adapted to a completely hiPSC-derived triculture system, we also generated myotubes from hiPSC [37] and successfully cocultured them with hiPSC-derived MN and SC (Figure S5). 
A
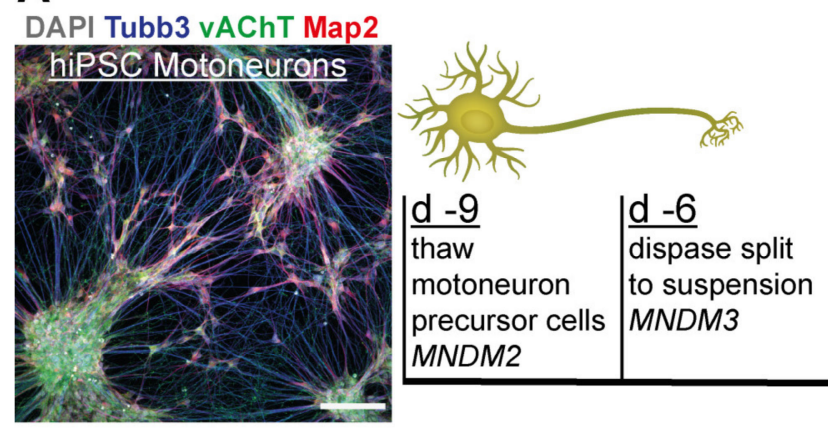

DAPI S100b Vimentin
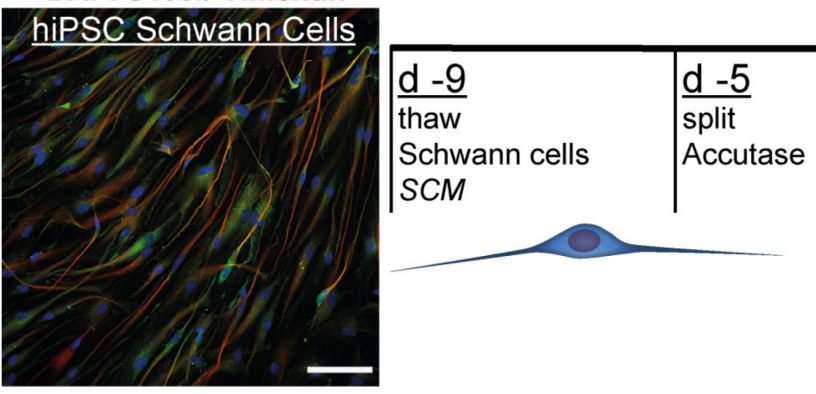

DAPI desmin

\section{C2C12 Myotubes}

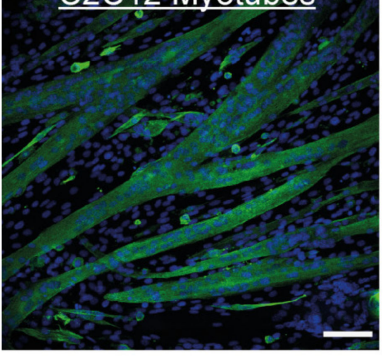

\begin{tabular}{|c|c|c|c|c|}
\hline 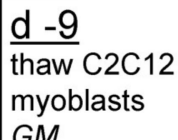 & $\begin{array}{l}\frac{d-6}{\text { split }} \\
\text { trypsin }\end{array}$ & $\frac{d-4}{\text { split }}$ & $\begin{array}{l}\frac{d-2}{\text { seed }} \\
\text { C2C12 }\end{array}$ & $\begin{array}{l}\frac{\mathrm{d}-1}{\mathrm{C} 2 \mathrm{C} 12} \\
D M\end{array}$ \\
\hline
\end{tabular}

\section{$\underline{\text { Triculture }}$}
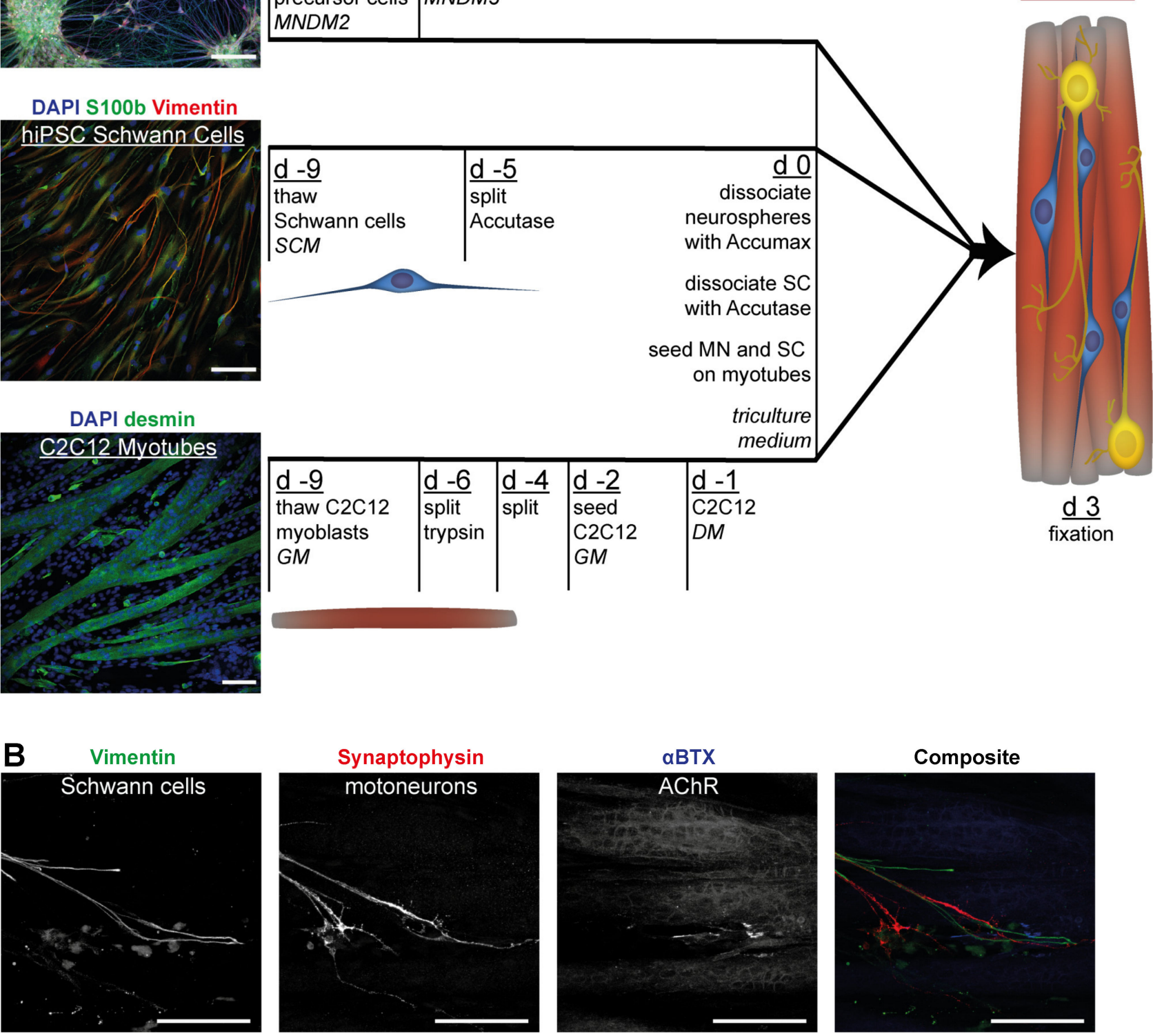

Figure 5. Tricultures can be set up from cell stocks within nine days. (A) Schematic timeline to set up tricultures, work steps, and different culture media shown. MNDM: MN differentiation medium; SCM: SC medium; GM: myoblast growth medium; DM: myotube differentiation medium. All medium compositions detailed in Methods section. Micrograph inserts depict fluorescence signals of representative individual cultures, respective stainings indicated on top of each panel. Scale bars: $100 \mu \mathrm{m}$. (B) Representative confocal image depicting SC (green in composite, Vimentin), MN (red in composite, Synaptophysin), and AChR clusters on C2C12 myotubes (blue in composite, $\alpha$ BTX staining). Scale bars: $50 \mu \mathrm{m}$.

\subsection{Cocultures Promote Formation of Myotubes with Increased Cytoplasmic Area}

Next, the effects of cocultures on myotube differentiation were addressed. To this end, $\mathrm{C} 2 \mathrm{C} 12$ cells were kept in either monoculture (C2C12 only), biculture (C2C12 combined with either $\mathrm{SC}$ or $\mathrm{MN})$, or triculture $(\mathrm{C} 2 \mathrm{C} 12, \mathrm{SC}$, and $\mathrm{MN})$; all conditions were cultured in triM. 
Cultures were immunostained against myosin heavy chain to visualize differentiated myotubes (MF20, Figure 6A). The microscopic assessment of myotubes led to the identification of two myotube populations: (i) myotubes with a large cytoplasmic area $\left(>200,000 \mu^{2}\right)$ and (ii) myotubes with a smaller cytoplasmic area $\left(<200,000 \mu \mathrm{m}^{2}\right)$. For both myotube populations, the mean percentage of coverage compared to the total area of the analyzed picture was determined for each culture condition. This showed that, starting with a value of $1.97 \pm 4.31 \%$ in $\mathrm{C} 2 \mathrm{C} 12$ monoculture (mean $\pm \mathrm{SD}$ ), the large-type myotubes increased the coverage upon biculture to $3.80 \pm 5.37 \%$ and $6.88 \pm 12.56 \%$ for $\mathrm{C} 2 \mathrm{C} 12+\mathrm{SC}$ and $\mathrm{C} 2 \mathrm{C} 12$ $+\mathrm{MN}$ bicultures, respectively. In the triculture condition, the large-type myotube coverage was further enhanced to $9.52 \pm 17.00 \%$ (Figure 6B). Conversely, coverage of myotubes with small cytoplasmic area was decreased in all coculture conditions compared to the $\mathrm{C} 2 \mathrm{C} 12$ monoculture condition. Differences were significant for the biculture with $\mathrm{MN}$ and the triculture condition $(4.31 \pm 0.02 \%$ for $\mathrm{C} 2 \mathrm{C} 12$ monocultures; $0.01 \pm 0.03 \%$ for $\mathrm{C} 2 \mathrm{C} 12+\mathrm{SC}$; $0.01 \pm 0.02 \%$ for $\mathrm{C} 2 \mathrm{C} 12+\mathrm{MN}$; and $0.009 \pm 0.02 \%$ for tricultures) (Figure $6 \mathrm{C}$ ). While the division of the myotube populations according to their area was preserved in the different coculture conditions, a progressive enlargement of the density curve for the large-type myotube population (Figure 6D, pink curves) was observed. This enlargement was slight in the biculture with $\mathrm{SC}$, was more pronounced in the biculture with $\mathrm{MN}$, and was even stronger in the tricultures (Figure 6D). All in all, these results indicated that the presence of SC and MN influence myogenesis in a synergistic manner.

\section{6. hiPSC-Derived MN and SC Influence Clustering of AChR on Myotubes In Vitro}

To investigate clustering of postsynaptic AChR on myotubes, AChR were stained with fluorescently labelled $\alpha$ BTX. Stained receptor clusters on myotubes were visualized by confocal fluorescence microscopy, segmented, and analyzed for their area, fluorescence intensity, and number. Results were compared for cultures of myotubes alone, $\mathrm{C} 2 \mathrm{C} 12$ bicultures with $\mathrm{MN}$ or SC, and tricultures. Figure 7A shows stainings for specific markers of the individual cell types in the different cocultures as well as representative segmented AChR clusters. Quantitative analysis of $\mathrm{AChR}$ mean cluster sizes revealed a significant reduction from $142.7 \pm 48.6 \mu \mathrm{m}^{2}$ in $\mathrm{C} 2 \mathrm{C} 12$ monocultures to $19.6 \pm 1.7 \mu \mathrm{m}^{2}$ and $22.4 \pm 5.0 \mu \mathrm{m}^{2}$ (mean $\pm \mathrm{SD}$ ) in $\mathrm{C} 2 \mathrm{C} 12+\mathrm{MN}$ and tricultures, respectively. In bicultures with SC, a trend towards decreased mean area $\left(90.5 \pm 31.3 \mu \mathrm{m}^{2}\right)$ was seen as well, but this was not statistically significant (Figure 7B). Regarding mean fluorescence intensity per cluster, an upward trend was found in cocultures when compared to myotubes alone, but the differences were not significant (Figure 7C). Finally, the number of segmented AChR clusters normalized to myotube area was analyzed. Compared to $16.2 \pm 15$ segmented clusters per $\mathrm{mm}^{2}$ myotube area in $\mathrm{C} 2 \mathrm{C} 12$ monocultures, the number of receptor clusters increased significantly in cocultures of myotubes and MN (112.8 \pm 9.0$)$. In tricultures, the number of clusters was also increased but to a lesser extent than in bicultures with $\mathrm{MN}\left(82.0 \pm 14.3\right.$ per $\mathrm{mm}^{2}$ in tricultures). In bicultures with Schwann cells, mean number per $\mathrm{mm}^{2}$ was $23.1 \pm 14.9$, showing no significant difference to C2C12 monoculture (Figure 7D). Additionally, myotubes were double-stained for the protein rapsyn, which is crucial for nerve-induced AChR clustering during muscle development (reviewed in [38]). In C2C12 monocultures, only $36.3 \pm 3.1 \%$ of segmented AChR clusters stained positive for rapsyn (Figure S6). This value increased significantly in biculture with $\mathrm{MN}(58.0 \pm 5.5 \%)$ and in tricultures $(60.2 \pm 1.9 \%)$. In bicultures with SC, $48.6 \pm 12.6 \%$ of segmented clusters were positive for rapsyn, showing a non-significant increasing trend (Figure S6). Taken together, these results confirm the inducing effect of hiPSC-derived MN on AChR cluster formation and suggest an additional influence of SC coculture. 
A
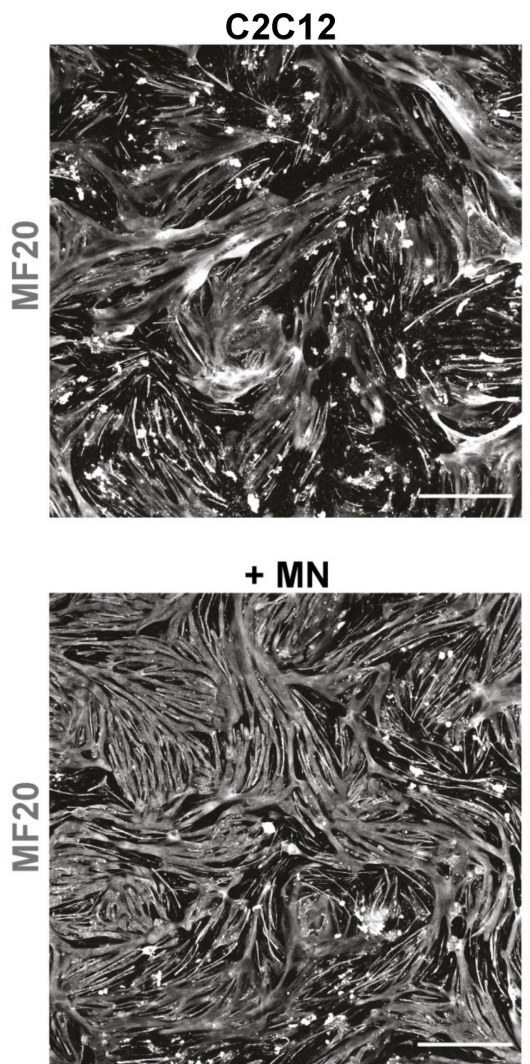

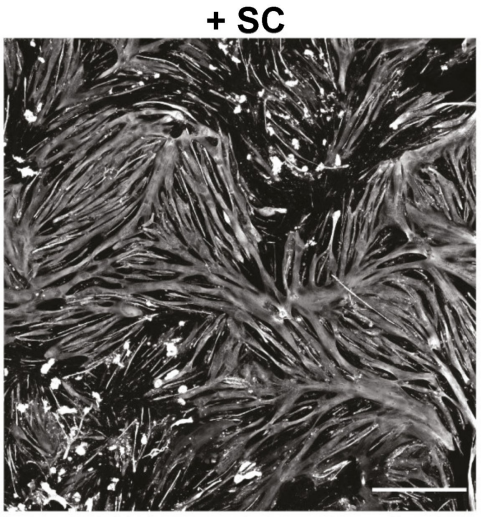

$+\mathrm{SC}+\mathrm{MN}$

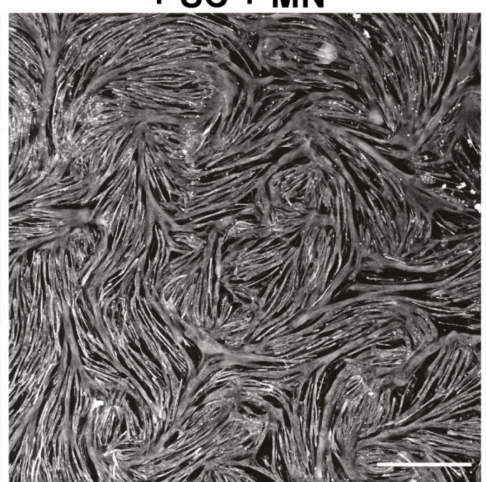

B

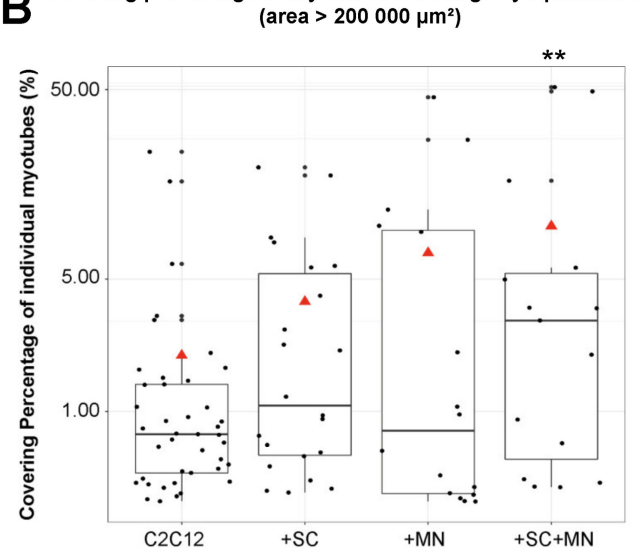

C

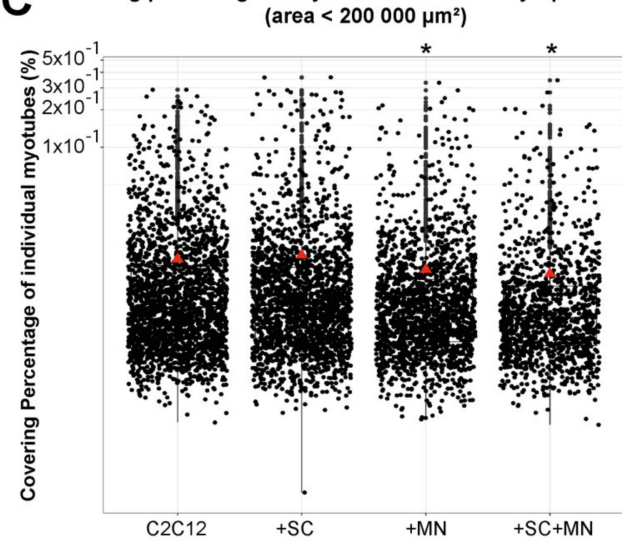

D Density of myotubes population by percentage of covering of each myotube

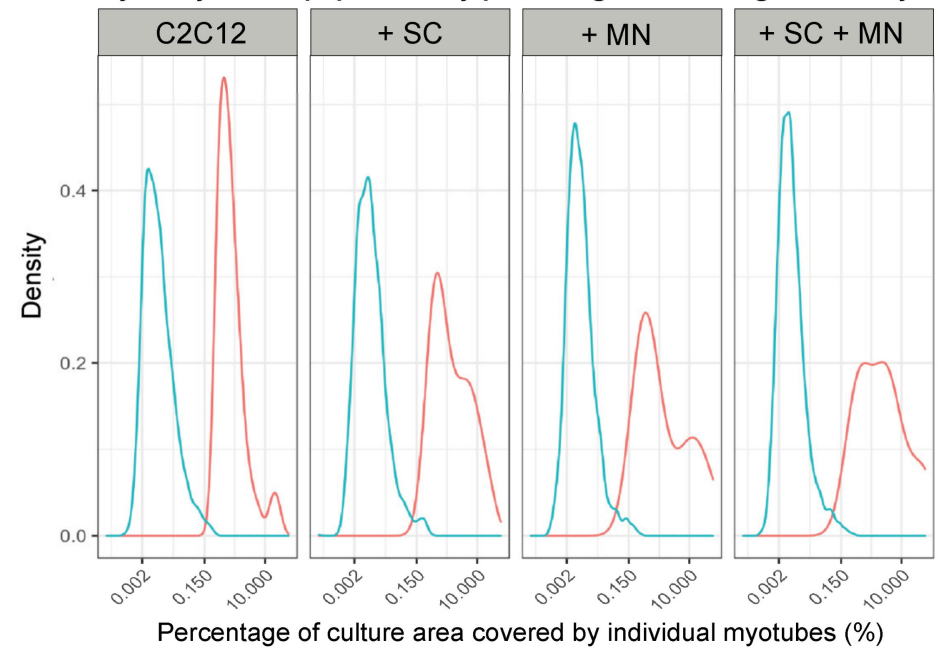

Figure 6. Cocultures promote formation of myotubes with increased cytoplasmic area. $\mathrm{C} 2 \mathrm{C} 12$ cells were cultured on cover slips for three days in the absence (C2C12) or presence of either SC (+ SC), MN (+ MN), or both (+ SC + MN). Then, cells were fixed and immunostained for the muscle cell marker myosin heavy chain (MF20). (A) Representative microscopic overviews of MF20 fluorescence signals under culture conditions as indicated. Scale bars: $1000 \mu \mathrm{m}$. (B,C) Quantification of covering area of myotubes classified into two populations: large-type myotubes $\left(>200,000 \mu \mathrm{m}^{2}\right)(\mathbf{B})$ and small-type myotubes $\left(<200,000 \mu \mathrm{m}^{2}\right)(C)$. Red triangles on boxplots indicate mean values for given conditions; $y$-axes logarithmic. ${ }^{*} p<0.05,{ }^{* *} p<0.01$. (D) Density curves of analyzed myotubes expressed according to their respective percentages of covering area of the total cellular culture area. Blue and pink lines: density curves for myotubes with low and high cytoplasmic area, respectively; $x$-axes logarithmic. 
A $\quad \mathrm{C}_{2} \mathrm{C} 12$
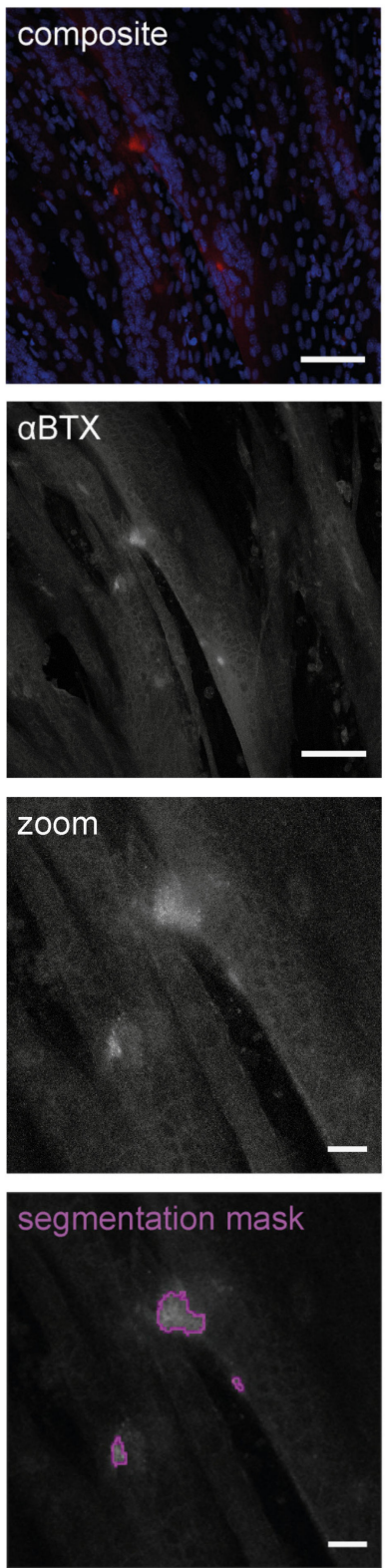

B

Mean Cluster Area

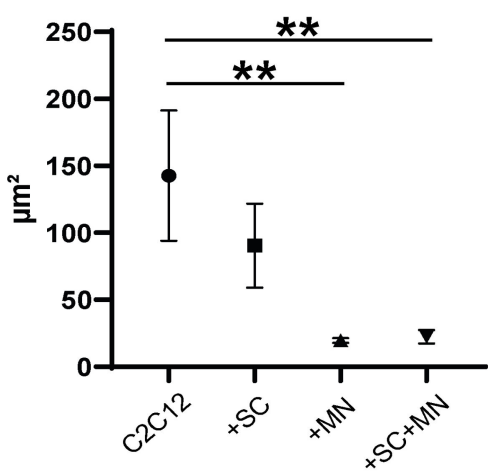

$+\mathrm{SC}$
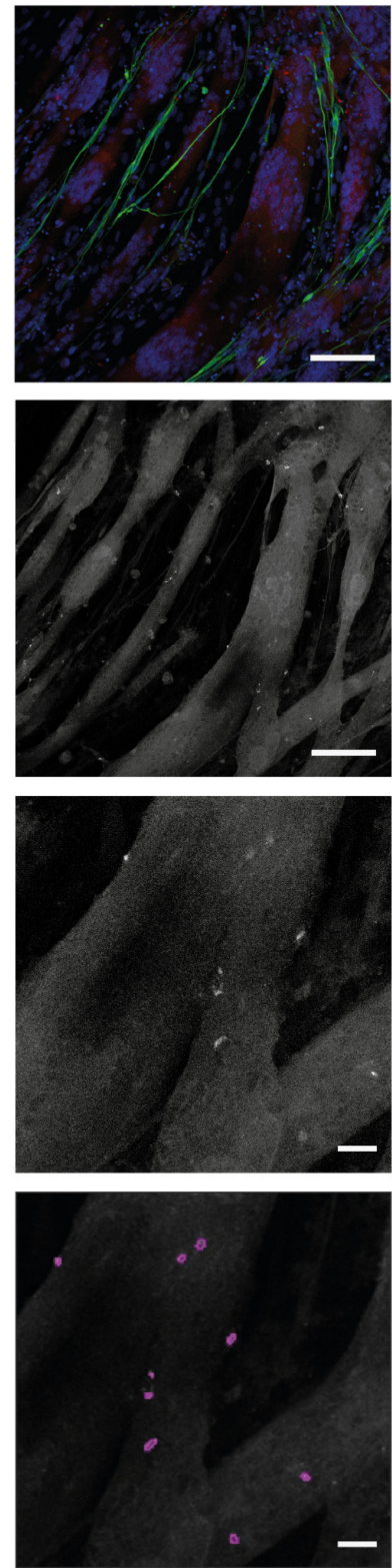

C Mean Cluster Intensity

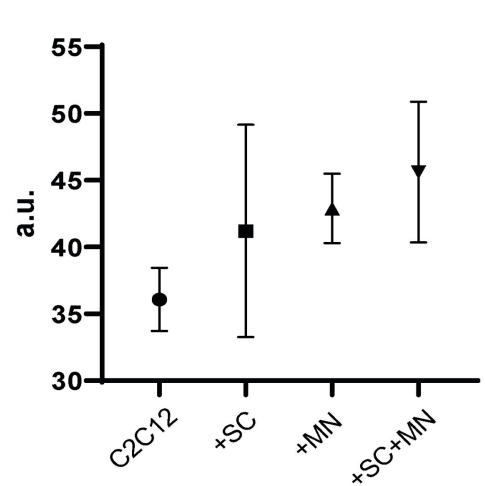

$+\mathrm{MN}$
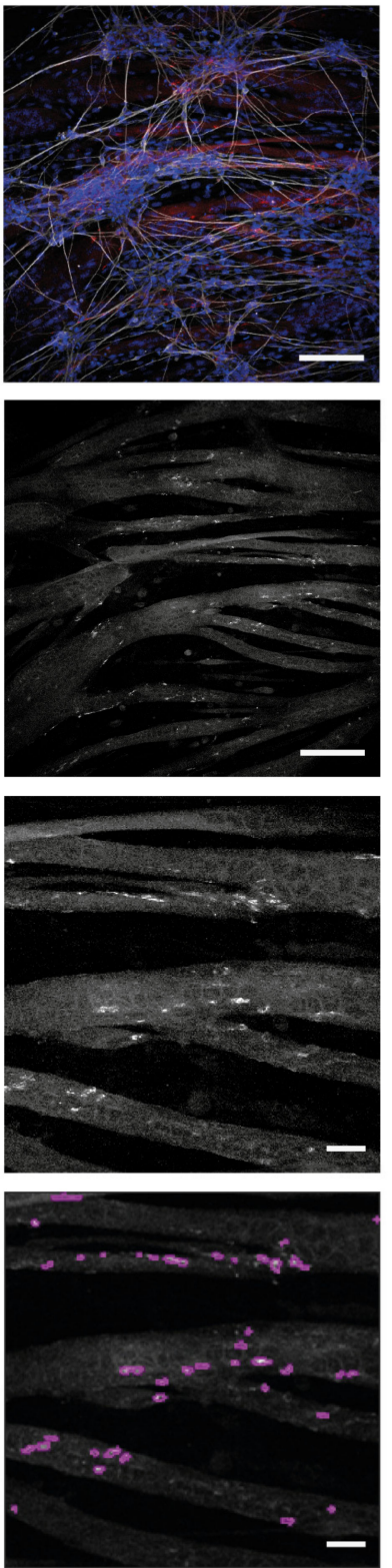

$+\mathrm{MN}+\mathrm{SC}$
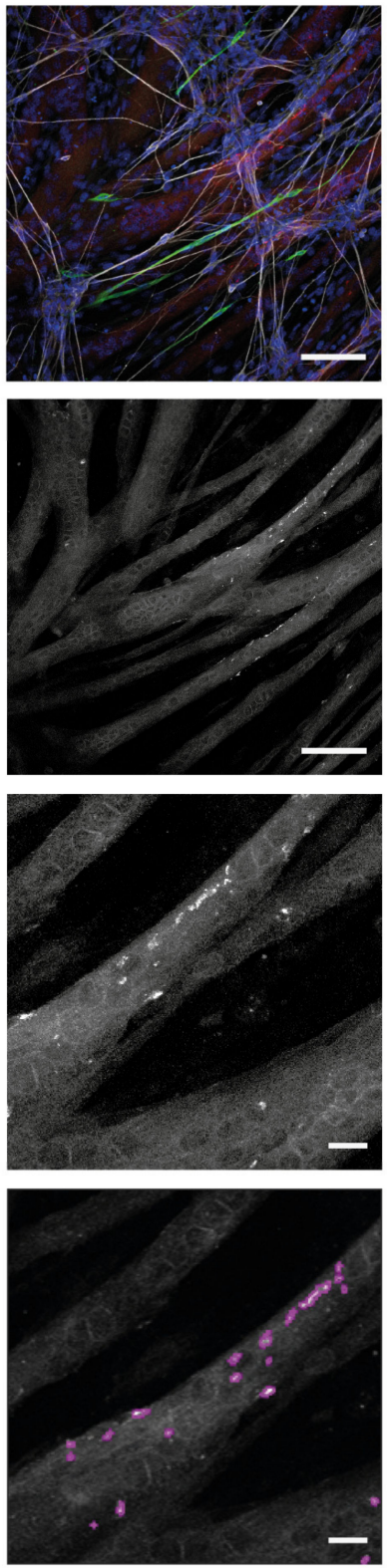

D Number of Clusters

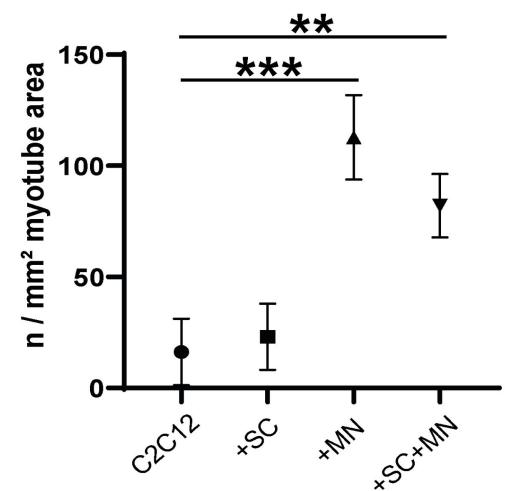

Figure 7. Cocultures with hiPSC motoneurons and Schwann cells influence formation of AChR clusters on C2C12 myotubes. $\mathrm{C} 2 \mathrm{C} 12$ cells were cultured on cover slips for three days in the absence (C2C12) or presence of SC (+ SC), MN 
$(+\mathrm{MN})$, or both $(+\mathrm{SC}+\mathrm{MN})$. Then, cells were fixed and stained for marker proteins, including AChR clusters. Upon confocal fluorescence microscopy, AChR clusters and their mean area, intensity, and number in the different coculture conditions were determined. (A) Representative confocal fluorescence images under culture conditions as indicated. Composite images showing fluorescence signals as follows. First row: DAPI (nuclei, blue), S100b (SC, green), $\beta$ III-tubulin (MN, gray), and $\alpha \mathrm{BTX}$ (AChR, red); second row: $\alpha \mathrm{BTX}$ staining only, in grays. Scale bars: $100 \mu \mathrm{m}$. Third and fourth rows show zoom images of representative AChR clusters and corresponding segmentation masks (purple outlines) as used for analysis. Scale bars: $20 \mu \mathrm{m}$. (B-D) Quantitative analysis of area of segmented AChR clusters (B), fluorescence intensity per segmented cluster $(\mathbf{C})$, and number of segmented clusters normalized to myotube area $(\mathbf{D})$ as a function of culture condition. All data, mean $\pm \mathrm{SD}(\mathrm{n}=3) .{ }^{* *} p<0.01,{ }^{* * *} p<0.001$.

\section{Discussion}

At the developing NMJ, SC are crucial for the formation of mature and stable synaptic contacts $[7,8,39]$. Even beyond synaptogenesis, SC remain an essential component of NMJs, regulating NMJ structure, function, and maintenance $[11,13,40,41]$ as well as NMJ plasticity and remodeling upon injury [14,42-44]. Despite being indispensable for NMJs in vivo, their integration into in vitro NMJ models has been recognized as an important feature $[1,3,6,45]$, but it was hampered by experimental pitfalls. Our current knowledge of SC biology is primarily obtained from animal models, and while some mechanisms translate from rodents to human biology, recent studies have revealed significant species differences of NMJ components [46] and, specifically, SC [47]. In the light of emerging roles of SC not only in synaptogenesis but also in neuromuscular diseases, the need for models with a human genetic background, which also include SC, is particularly relevant.

For example, in several SOD1 mutant mouse models, which are widely used to study pathology of amyotrophic lateral sclerosis (ALS), alterations in SC activity and morphology precede denervation of NMJs and impede NMJ repair [48-50]. Interestingly, altered SC morphology is also seen in ALS patients [51,52]. However, species-specific differences complicate translation of disease signs and mechanisms. In comparison to mice, SC at healthy human NMJs exhibit higher non-synaptic placement of their nuclei along with less AChR coverage, which in SOD1 mutant mice would both be associated with pathological changes [53]. Indeed, mouse model data have so far not been able to translate well into treatments for human ALS [54]. Therefore, integration of human SC would likely advance the relevance of stem-cell based models not only for studying cell type interactions at the healthy NMJ but also for disease modeling and, ultimately, drug testing. So far, selective integration of human SC into neuromuscular cocultures has been impaired by several factors: (i) introduction of a third cell type in defined cocultures considerably increases complexity of the culture model [2]; (ii) protocols to derive SC from hiPSC are sparse, often coming with low yields, purification steps, and long differentiation times [21]; and (iii) differentiation protocols to specifically derive terminal SC are not available, since exact developmental switches necessary for their specification are elusive [55]. In this work, we provide a protocol to set up tricultures comprised of hiPSC-derived SC, MN, and C2C12 myotubes in only nine days from frozen cell stocks.

To achieve this, we present an improved differentiation protocol to derive human SC from hiPSC with increased robustness. When employing a SC differentiation protocol which does not necessitate purification steps [24], a secondary cell population positive for SOX2 but negative for SOX10 was frequently observed, suggesting insufficient neural crest induction. This was in accordance with literature, where oftentimes low cell yields are reported in differentiation protocols for obtaining neural crest in general and, specifically, SC $[21,36]$. A possible reason could be insufficient activation of BMP signaling, which is required for neural crest specification [56]. However, deliberate BMP activation by small molecules can also antagonize neural crest specification [57], and timing regarding the differentiation process is crucial [58]. The work of Hackland et al. proved that precise activation of BMP signaling to an intermediate level is necessary for the development of neural crest cells and demonstrated the presence of different levels of endogenous BMP between different PSC lines and experiments. Their findings explain previous conflicting 
results regarding either promotion or inhibition of neural crest specification upon BMP activation in cell culture and could also be a reason for low cell yields or varying differentiation success between distinct PSC lines and differentiation batches in SC differentiation protocols. In such protocols, which do not add compounds to interfere with BMP signaling, differentiation efficiency would possibly depend on inherent BMP signaling levels in PSC lines and culture systems used. Consequently, we explored a top-down inhibition system as suggested by Hackland et al., i.e., saturating with BMP4 exogenously while using the BMP antagonist DMH1 to attenuate signaling to a precise level. In accordance with their results, efficient and robust derivation of SOX10+ neural crest cells could be achieved, and these cells were found to be competent to further differentiate along the SC lineage.

Since non-defined media constituents such as serum are subject to batch-to-batch variation and may contain components which affect BMP signaling or other relevant pathways, thereby possibly increasing protocol variability, we explored xeno-free medium formulations for differentiation. SC precursor cells derived after 24 days of differentiation were obtained in completely defined medium conditions without addition of BSA, which is frequently used in this step. Usage of BSA can potentially affect signaling during differentiation, since it acts as a carrier protein and might be bound to molecules influencing signaling targets or activity of small molecules added for differentiation [36,59]. Indeed, we obtained SC precursors using a concentration of Activin/Nodal/TGF- $\beta$ pathway inhibitor SB431542 reported for stem cell neuralization and also neural crest specification in chemically defined conditions [36,60]. Conversely, protocols involving BSA often require 10-fold higher concentrations of that molecule [24,57,61]. Thus, while SC precursor derivation could be obtained in a xeno-free manner, addition of FBS following day 24 of differentiation was necessary to mature SC precursors into SC without contaminating cell populations. Although in serum-free medium containing N2 and SM1 supplements, a population of differentiating SC expressing S100b was observed as well, and cell yields and differentiation efficiency were drastically decreased. Potentially, the present protocol could be adapted to be serum-free by introducing a cell-sorting step. This would render it suitable for applications requiring the use of defined xeno-free media throughout the whole differentiation period, such as for clinical tissue engineering. Even if experimental design allows the use of serum for differentiation of cells, it would be desirable to perform subsequent experiments in defined, serum-free conditions to avoid variable and hard to predict interferences from such compounds. The medium formulation here presented for the culture of NMJ tricultures fulfilled these requirements and also supported hiPSC-derived $\mathrm{SC}$ in monoculture after a preceding maturation phase in serum-containing medium.

Moreover, switching SC to the serum-free triculture medium (triM) seemed to improve cell differentiation, and possibly maturation, after only three days of culture, as determined by their more elongated, characteristic spindle-like morphology, their increase in expression of the SC markers myelin protein zero (P0) and S100b, and a decrease in proliferation. Our results suggest that this effect was mainly mediated by retinoic acid (RA), since proliferation was decreased and $\mathrm{P} 0$ expression as well as cell elongation were increased in all conditions containing this factor. RA is a crucial patterning and maturation factor in neural development and drives posterior specification of trunk identity in neural crest differentiation $[62,63]$. Furthermore, it is included in a number of differentiation protocols which generate SC or Schwann-like cells from human stem cells or other cell sources, including mesenchymal stem cells, adipose-derived stem cells, or fibroblasts [24,64-66]. SC express retinoid receptors during development and in adult peripheral nerve, and RA can exert different functions on SC, suggesting a key role for retinoic signaling in SC physiology [67]. Moreover, RA appeared to act in synergy with ascorbic acid. Ascorbic acid is known to promote SC basal lamina assembly and myelin formation [68,69], and it is frequently added in cocultures of SC with primary neurons to induce myelination $[22,23,70]$. This induction of the myelination program is accompanied by a shifting to a differentiated postmitotic state and upregulation of protein expression related to myelination, including P0 [71,72], but all exact mechanisms of action have not been elucidated yet [68]. RA, on the other hand, 
was found to inhibit myelination in primary explant cultures of mouse and rat peripheral nerve [73]. Nevertheless, this mechanism was accompanied by increased expression of P0, which is in accordance with our findings. Further studies in the same system also revealed an inhibitory effect of RA on SC proliferation [74]. However, the mechanism downstream of this antiproliferative and potentially maturating effect has yet to be elucidated, as well as other possibly co-regulated pathways. Altogether, our findings provide valuable benefits to protocols for differentiation of SC from hiPSC currently available in the literature. Further experiments would be advisable to find the optimal medium formulation for hiPSC-derived SC maturation if NMJ tricultures are not the primary experimental goal.

For our study, these hiPSC-derived SC were used to set up tricultures in combination with hiPSC-derived $\mathrm{MN}$ and $\mathrm{C} 2 \mathrm{C} 12$ myotubes. While the interplay between muscle cells, $\mathrm{SC}$, and $\mathrm{MN}$ is known to be crucial to form and mature functional NMJs, the importance of their crosstalk on differentiating muscle cell homeostasis is still puzzling. In the current work, the presence of SC and MN was demonstrated to influence myogenesis in a synergistic manner. This finding may be explained by the secretory activities of $\mathrm{MN}$ and SC that trigger different biological processes. Indeed, SC can secrete several different neurotrophins, and Kim et al. demonstrated expression and secretion of BDNF, GDNF, NGF, and NT-3 by hiPSC-derived SC. These are known to exert pleiotropic effects on diverse cell types and tissues. Amongst the targeted tissues, skeletal muscle cells express receptors for various growth factors, suggesting that neurotrophic signaling could play a crucial role in the myogenic process [75-78]. While the lack of NT-3 or its receptor, TrkC, considerably alter mobility $[79,80]$, the BDNF pathway was highlighted as a major factor in skeletal muscle regeneration and myogenesis [81-83]. BDNF may act as an autocrine/paracrine factor that transcriptionally regulates metabolism in muscle cells [84]. Additionally, NGF was described to regulate cellular homeostasis and inflammatory status in skeletal muscle fibers [85,86]. Similarly, MN are also known to release important paracrine factors that modulate muscle cell physiology. Amongst these, agrin is a key factor for clustering AChR at developing NMJs via the agrin/Lrp4/Musk pathway [87,88]. It can also induce rapsyn stabilization at AChR clusters [89-92]. In alignment with that, we found increased percentages of AChR clusters positive for rapsyn in myotubes cocultured with MN. In bicultures of myotubes and SC, trends towards increased numbers of AChR clusters and of rapsyn-positive clusters were observed. Although these changes were not statistically significant, they were in the same order of magnitude (1.42-fold and 1.34-fold increase for number of clusters and percentage of rapsyn-positive clusters, respectively) and were accompanied by a general change of appearance of AChR clusters; while some of them resembled the larger and more diffuse clusters observed in $\mathrm{C} 2 \mathrm{C} 12$ monocultures, others were rather similar to the smaller and more defined clusters found in cocultures with $\mathrm{MN}$. In fact, primary SC at the NMJ were reported to express an isoform of agrin which is able to enhance AChR clustering, although with lower efficiency than neural agrin [7,93-95].

Next, in tricultures, the number of $\mathrm{AChR}$ clusters was decreased when compared to bicultures with only $\mathrm{MN}$ (0.73-fold decrease). Considering that SC are coordinators of synapse elimination in NMJ development and they are able to selectively stabilize or destabilize synaptic contacts to achieve matured innervation $[10,96,97]$, this finding would be potentially interesting. One possible mode of action for the loss of AChR clusters could be a direct influence of SC on MN-derived agrin levels. At NMJs, matrix metalloproteinase- 3 secreted by terminal SCs was found to cleave agrin and reduce its concentration in the synaptic basal lamina [98-100]. Conversely, AChR aggregates were increased in matrix metalloproteinase-3 null mice [101,102]. Moreover, experiments in chick and Xenopus myotubes showed that several trophic factors, some of which have been shown to be expressed by hiPSC-derived SC [24], can lead to suppression of AChR clustering via inhibition of agrin synthesis and enhanced transmitter release in MN $[103,104]$. In development, $\mathrm{AChR}$ expression, clustering, and stabilization are regulated positively by agrin and negatively by ACh. While ACh exerts its effects globally, agrin acts locally to stabilize only directly innervated AChR clusters, thus leading to a destabilization of aneural 
clusters $[87,105,106]$. An increase in ACh release by MN induced by SC-secreted neurotrophic factors could, therefore, lead to destabilization of AChR clusters not in direct contact with neurites and, hence, account for the decreased number of AChR clusters in tricultures.

The protocol to set up tricultures presented in this work employed the straightforward two-layer 2D culturing method that has been widely used for neuromuscular cultures. This makes it flexible and easy to implement with already established in vitro NMJ models accessible for analysis via imaging and molecular assays. Other authors have reported functionality of in vitro NMJs from different cell sources [107-109]. This was done by evaluating muscle contraction upon excitation of $\mathrm{MN}$, either by glutamate $[110,111]$ or optogenetic $[112,113]$ or electrophysiological $[108,114]$ stimulation and by testing the specificity of transmission response by antagonists which either blocked ACh release or binding $[16,107,115]$. In this context, it would be informative to integrate hiPSC-derived SC into NMJ culture systems suited for such readouts in order to evaluate a possible impact on in vitro NMJ functionality. Moreover, besides functionality, it would be of interest whether hiPSC-derived SC are able to increase maturity of in vitro NMJs. One method to judge maturation is to evaluate the switch of the embryonic gamma subunit to the adult epsilon subunit in AChR; however, in vitro, this has been demonstrated so far only in advanced explant or engineered 3D cultures $[16,111,112]$. Recent work has shown enormous benefit of 3D culture methods on stability, maturity, and organization of neuromuscular culture models and demonstrated their potential for disease modeling $[107,111,113,116]$. Since myotubes tend to detach from rigid culture substrates over time and are, therefore, not suited for long-term experiments in 2D cultures [117,118], long-term studies concerning in vitro NMJ maturation and stabilization would require such 3D culture approaches. Therefore, to explore its full potential, the triculture model should be ultimately advanced to a suited 3D culture platform. Such cultures could potentially be used for studying early NMJ development in vitro and the contribution of the distinct cellular partners to synapse formation and stabilization as well as the effect of the presence of SC on differentiation of the other cell types and vice versa. In stable long-term models, SC differentiation could be further advanced and explored, for example, by checking for distinct specification into myelinating and non-myelinating subtypes or even possible SC responses upon modeling injuries which are seen in vivo $[44,119]$. Furthermore, the use of hiPSC opens the possibility for cell type-targeted disease modeling. Besides comparing cultures completely derived from patient hiPSC with control cultures, it would be possible to create models in which only one of the three cell types is derived from patient cells in order to elucidate cell typespecific contributions to disease mechanisms. Along these lines, we have demonstrated the possibility to set up tricultures from hiPSC-derived cells only, including hiPSC-derived muscle cells as well, and future work will focus on robust protocols to create isogenic human tricultures and transferring them to 3D.

\section{Conclusions}

The presented triculture model is the first to show selective and controlled integration of SC which were separately differentiated from hiPSC with improved robustness into neuromuscular cocultures. It paves the way for further studies and more complex models exploring their role in maturation and pathological mechanisms at the NMJ. Adapting the protocol to more advanced 3D culture systems to enable long-term studies will open possibilities for studying the influence of hiPSC-derived SC on in vitro NMJ formation and maturation and also the cues potentially provided by the other cells which affect SC differentiation and their specification to a terminal SC fate.

Supplementary Materials: The following are available online at https:/ /www.mdpi.com/article/10 .3390 / cells10123292/s1, Figure S1: Representative micrographs of marker protein immunostainings for hiPSC-derived motoneurons; Figure S2: Schwann cell differentiation in defined conditions; Figure S3: Representative micrographs of marker protein immunostaining panel for different Schwann cell maturation media conditions; Figure S4: Cell types colocalize and align in tricultures; Figure S5: 
Completely hiPSC-derived NMJ tricultures; Figure S6: Cocultures increase percentage of AChR clusters positive for rapsyn staining; Table S1: Antibodies used for immunofluorescence stainings.

Author Contributions: Conceptualization, S.J.H. and R.R.; methodology, S.J.H., N.C., and R.B.; software, R.B.; validation, S.J.H. and N.C.; formal analysis, S.J.H., N.C., and R.B.; investigation, S.J.H. and N.C.; resources, P.K., M.H., and R.R.; data curation, S.J.H., N.C., and R.B.; writing — original draft preparation, S.J.H., N.C., and R.B.; writing-review and editing, S.J.H., P.K., M.H., and R.R.; visualization, S.J.H., N.C., and R.B.; supervision, M.H. and R.R.; project administration, R.R.; funding acquisition, M.H. and R.R. All authors have read and agreed to the published version of the manuscript.

Funding: S.J.H. was funded by a fellowship of the Albert und Anneliese Konanz-Stiftung. P.K. and S.J.H. acknowledge the support of the Hector Stiftung II. This work was funded by the German Federal Ministry of Research (BMBF) as part of the Innovation Partnership $\mathrm{M}^{2}$ Aind, projects $\mathrm{M}^{2} \mathrm{OGA}$ (03FH8I02IA) and Drugs4Future (13FH8I05IA) within the framework Starke Fachhochschulen-Impuls für die Region (FH-Impuls).

Institutional Review Board Statement: Not applicable.

Informed Consent Statement: Not applicable.

Data Availability Statement: All experimental data will be available upon request.

Conflicts of Interest: The authors declare no conflict of interest.

\section{References}

1. Barbeau, S.; Tahraoui-Bories, J.; Legay, C.; Martinat, C. Building neuromuscular junctions in vitro. Development 2020, 147, dev193920. [CrossRef] [PubMed]

2. Natarajan, A.; Sethumadhavan, A.; Krishnan, U.M. Toward Building the Neuromuscular Junction: In Vitro Models to Study Synaptogenesis and Neurodegeneration. ACS Omega 2019, 4, 12969-12977. [CrossRef] [PubMed]

3. Castellanos-Montiel, M.J.; Velasco, I.; Escobedo-Avila, I. Modeling the neuromuscular junction in vitro: An approach to study neuromuscular junction disorders. Ann. N. Y. Acad. Sci. 2020, 14388, 3-15. [CrossRef] [PubMed]

4. Vila, O.F.; Qu, Y.; Vunjak-Novakovic, G. In vitro models of neuromuscular junctions and their potential for novel drug discovery and development. Expert Opin. Drug Discov. 2020, 15, 307-317. [CrossRef] [PubMed]

5. Lynch, E.; Peek, E.; Reilly, M.; FitzGibbons, C.; Robertson, S.; Suzuki, M. Current Progress in the Creation, Characterization, and Application of Human Stem Cell-derived in Vitro Neuromuscular Junction Models. Stem Cell Rev. Rep. 2021. [CrossRef] [PubMed]

6. Luttrell, S.M.; Smith, A.S.T.; Mack, D.L. Creating stem cell-derived neuromuscular junctions in vitro. Muscle Nerve 2021, 64, 388-403. [CrossRef]

7. Darabid, H.; Perez-Gonzalez, A.P.; Robitaille, R. Neuromuscular synaptogenesis: Coordinating partners with multiple functions. Nat. Rev. Neurosci. 2014, 15, 703-718. [CrossRef] [PubMed]

8. Feng, Z.; Ko, C.-P. The role of glial cells in the formation and maintenance of the neuromuscular junction. Ann. N. Y. Acad. Sci. 2008, 1132, 19-28. [CrossRef]

9. Reddy, L.V.; Koirala, S.; Sugiura, Y.; Herrera, A.A.; Ko, C.P. Glial cells maintain synaptic structure and function and promote development of the neuromuscular junction in vivo. Neuron 2003, 40,563-580. [CrossRef]

10. Darabid, H.; St-Pierre-See, A.; Robitaille, R. Purinergic-Dependent Glial Regulation of Synaptic Plasticity of Competing Terminals and Synapse Elimination at the Neuromuscular Junction. Cell Rep. 2018, 25, 2070-2082.e6. [CrossRef]

11. Barik, A.; Li, L.; Sathyamurthy, A.; Xiong, W.-C.; Mei, L. Schwann Cells in Neuromuscular Junction Formation and Maintenance. J. Neurosci. Off. J. Soc. Neurosci. 2016, 36, 9770-9781. [CrossRef] [PubMed]

12. Darabid, H.; Arbour, D.; Robitaille, R. Glial cells decipher synaptic competition at the mammalian neuromuscular junction. J. Neurosci. Off. J. Soc. Neurosci. 2013, 33, 1297-1313. [CrossRef]

13. Alvarez-Suarez, P.; Gawor, M.; Prószyński, T.J. Perisynaptic schwann cells-The multitasking cells at the developing neuromuscular junctions. Semin. Cell Dev. Biol. 2020, 104, 31-38. [CrossRef]

14. Ko, C.-P.; Robitaille, R. Perisynaptic Schwann Cells at the Neuromuscular Synapse: Adaptable, Multitasking Glial Cells. Cold Spring Harb. Perspect. Biol. 2015, 7, a020503. [CrossRef] [PubMed]

15. Singh, T.; Vazquez, M. Time-Dependent Addition of Neuronal and Schwann Cells Increase Myotube Viability and Length in an In Vitro Tri-culture Model of the Neuromuscular Junction. Regen. Eng. Transl. Med. 2019, 22, 389. [CrossRef]

16. Vilmont, V.; Cadot, B.; Ouanounou, G.; Gomes, E.R. A system for studying mechanisms of neuromuscular junction development and maintenance. Development 2016, 143, 2464-2477. [CrossRef] [PubMed]

17. Mars, T.; Yu, K.J.; Tang, X.M.; Miranda, A.F.; Grubic, Z.; Cambi, F.; King, M.P. Differentiation of glial cells and motor neurons during the formation of neuromuscular junctions in cocultures of rat spinal cord explant and human muscle. J. Comp. Neurol. 2001, 438, 239-251. [CrossRef] [PubMed] 
18. Southam, K.A.; King, A.E.; Blizzard, C.A.; McCormack, G.H.; Dickson, T.C. Microfluidic primary culture model of the lower motor neuron-neuromuscular junction circuit. J. Neurosci. Methods 2013, 218, 164-169. [CrossRef] [PubMed]

19. Faustino Martins, J.-M.; Fischer, C.; Urzi, A.; Vidal, R.; Kunz, S.; Ruffault, P.-L.; Kabuss, L.; Hube, I.; Gazzerro, E.; Birchmeier, C.; et al. Self-Organizing 3D Human Trunk Neuromuscular Organoids. Cell Stem Cell 2020. [CrossRef] [PubMed]

20. Lin, C.-Y.; Yoshida, M.; Li, L.-T.; Ikenaka, A.; Oshima, S.; Nakagawa, K.; Sakurai, H.; Matsui, E.; Nakahata, T.; Saito, M.K. iPSC-derived functional human neuromuscular junctions model the pathophysiology of neuromuscular diseases. JCI Insight 2019, 4, e124299. [CrossRef] [PubMed]

21. Huang, Z.; Powell, R.; Phillips, J.B.; Haastert-Talini, K. Perspective on Schwann Cells Derived from Induced Pluripotent Stem Cells in Peripheral Nerve Tissue Engineering. Cells 2020, 9, 2497. [CrossRef]

22. Liu, Q.; Spusta, S.C.; Mi, R.; Lassiter, R.N.T.; Stark, M.R.; Höke, A.; Rao, M.S.; Zeng, X. Human Neural Crest Stem Cells Derived from Human ESCs and Induced Pluripotent Stem Cells: Induction, Maintenance, and Differentiation into Functional Schwann Cells. STEM CELLS Transl. Med. 2012, 1, 266-278. [CrossRef] [PubMed]

23. Ziegler, L.; Grigoryan, S.; Yang, I.H.; Thakor, N.V.; Goldstein, R.S. Efficient Generation of Schwann Cells from Human Embryonic Stem Cell-Derived Neurospheres. Stem Cell Rev. 2011, 7, 394-403. [CrossRef]

24. Kim, H.-S.; Lee, J.; Lee, D.Y.; Kim, Y.-D.; Kim, J.Y.; Lim, H.J.; Lim, S.; Cho, Y.S. Schwann Cell Precursors from Human Pluripotent Stem Cells as a Potential Therapeutic Target for Myelin Repair. Stem Cell Rep. 2017, 8, 1714-1726. [CrossRef] [PubMed]

25. Chen, H.; Qian, K.; Du, Z.; Cao, J.; Petersen, A.; Liu, H.; Blackbourn, L.W.; Huang, C.-L.; Errigo, A.; Yin, Y.; et al. Modeling ALS with iPSCs Reveals that Mutant SOD1 Misregulates Neurofilament Balance in Motor Neurons. Cell Stem Cell 2014, 14, 796-809. [CrossRef]

26. Du, Z.-W.; Chen, H.; Liu, H.; Lu, J.; Qian, K.; Huang, C.-L.; Zhong, X.; Fan, F.; Zhang, S.-C. Generation and expansion of highly pure motor neuron progenitors from human pluripotent stem cells. Nat. Commun. 2015, 6, 6626. [CrossRef] [PubMed]

27. Scherr, T.; Streule, K.; Bartschat, A.; Böhland, M.; Stegmaier, J.; Reischl, M.; Orian-Rousseau, V.; Mikut, R. Bead Net: Deep learning-based bead detection and counting in low-resolution microscopy images. Bioinformatics 2020, 36, 4668-4670. [CrossRef]

28. Stegmaier, J.; Otte, J.C.; Kobitski, A.; Bartschat, A.; Garcia, A.; Nienhaus, G.U.; Strähle, U.; Mikut, R. Fast segmentation of stained nuclei in terabyte-scale, time resolved 3D microscopy image stacks. PLoS ONE 2014, 9, e90036. [CrossRef] [PubMed]

29. Bartschat, A.; Hübner, E.; Reischl, M.; Mikut, R.; Stegmaier, J. XPIWIT-an XML pipeline wrapper for the Insight Toolkit. Bioinformatics 2016, 32, 315-317. [CrossRef] [PubMed]

30. Schindelin, J.; Arganda-Carreras, I.; Frise, E.; Kaynig, V.; Longair, M.; Pietzsch, T.; Preibisch, S.; Rueden, C.; Saalfeld, S.; Schmid, B.; et al. Fiji: An open-source platform for biological-image analysis. Nat. Methods 2012, 9, 676-682. [CrossRef] [PubMed]

31. Wickham, H.; Francois, R.; Henry, L.; Müller, K.; dplyr: A Grammar of Data Manipulation. R package version 1.0.6. 2021. Available online: https: / / dplyr.tidyverse.org (accessed on 21 November 2021).

32. Wickham, H. ggplot2: Elegant Graphics for Data Analysis. Springer-Verlag New York. 2016. Available online: https://ggplot2 .tidyverse.org (accessed on 21 November 2021).

33. Wickham, H.; Seidel, D. Scales: Scale Functions for Visualization, R package version 1.1.1; 2020. Available online: https:/ /scales.rlib.org (accessed on 21 November 2021).

34. Bates, D.; Mächler, M.; Bolker, B.; Walker, S. Fitting Linear Mixed-Effects Models Using lme4. J. Stat. Soft. 2015, 67, 1-48. [CrossRef]

35. Yi, H.; Xie, B.; Liu, B.; Wang, X.; Xu, L.; Liu, J.; Li, M.; Zhong, X.; Peng, F. Derivation and Identification of Motor Neurons from Human Urine-Derived Induced Pluripotent Stem Cells. Stem Cells Int. 2018, 2018, 3628578. [CrossRef] [PubMed]

36. Hackland, J.O.S.; Frith, T.J.R.; Thompson, O.; Marin Navarro, A.; Garcia-Castro, M.I.; Unger, C.; Andrews, P.W. Top-Down Inhibition of BMP Signaling Enables Robust Induction of hPSCs Into Neural Crest in Fully Defined, Xeno-free Conditions. Stem Cell Rep. 2017, 9, 1043-1052. [CrossRef] [PubMed]

37. Chal, J.; Al Tanoury, Z.; Hestin, M.; Gobert, B.; Aivio, S.; Hick, A.; Cherrier, T.; Nesmith, A.P.; Parker, K.K.; Pourquié, O. Generation of human muscle fibers and satellite-like cells from human pluripotent stem cells in vitro. Nat. Protoc. 2016, 11, 1833-1850. [CrossRef] [PubMed]

38. Xing, G.; Xiong, W.-C.; Mei, L. Rapsyn as a signaling and scaffolding molecule in neuromuscular junction formation and maintenance. Neurosci. Lett. 2020, 731, 135013. [CrossRef] [PubMed]

39. Koirala, S.; Reddy, L.V.; Ko, C.-P. Roles of glial cells in the formation, function, and maintenance of the neuromuscular junction. $J$. Neurocytol. 2003, 32, 987-1002. [CrossRef] [PubMed]

40. Petrov, K.A.; Girard, E.; Nikitashina, A.D.; Colasante, C.; Bernard, V.; Nurullin, L.; Leroy, J.; Samigullin, D.; Colak, O.; Nikolsky, E.; et al. Schwann cells sense and control acetylcholine spillover at the neuromuscular junction by $\alpha 7$ nicotinic receptors and butyrylcholinesterase. J. Neurosci. Off. J. Soc. Neurosci. 2014, 34, 11870-11883. [CrossRef] [PubMed]

41. Griffin, J.W.; Thompson, W.J. Biology and pathology of nonmyelinating Schwann cells. Glia 2008, 56, 1518-1531. [CrossRef]

42. Negro, S.; Lessi, F.; Duregotti, E.; Aretini, P.; La Ferla, M.; Franceschi, S.; Menicagli, M.; Bergamin, E.; Radice, E.; Thelen, M.; et al. CXCL12 $\alpha /$ SDF-1 from perisynaptic Schwann cells promotes regeneration of injured motor axon terminals. EMBO Mol. Med. 2017, 9, 1000-1010. [CrossRef] [PubMed]

43. Duregotti, E.; Negro, S.; Scorzeto, M.; Zornetta, I.; Dickinson, B.C.; Chang, C.J.; Montecucco, C.; Rigoni, M. Mitochondrial alarmins released by degenerating motor axon terminals activate perisynaptic Schwann cells. Proc. Natl. Acad. Sci. USA 2015, 112, E497-E505. [CrossRef] [PubMed] 
44. Kang, H.; Tian, L.; Mikesh, M.; Lichtman, J.W.; Thompson, W.J. Terminal Schwann cells participate in neuromuscular synapse remodeling during reinnervation following nerve injury. J. Neurosci. 2014, 34, 6323-6333. [CrossRef]

45. Legay, C.; Mei, L. Moving forward with the neuromuscular junction. J. Neurochem. 2017, 142, 59-63. [CrossRef] [PubMed]

46. Jones, R.A.; Harrison, C.; Eaton, S.L.; Llavero Hurtado, M.; Graham, L.C.; Alkhammash, L.; Oladiran, O.A.; Gale, A.; Lamont, D.J.; Simpson, H.; et al. Cellular and Molecular Anatomy of the Human Neuromuscular Junction. Cell Rep. 2017, 21, $2348-2356$. [CrossRef]

47. Alhindi, A.; Boehm, I.; Forsythe, R.O.; Miller, J.; Skipworth, R.J.E.; Simpson, H.; Jones, R.A.; Gillingwater, T.H. Terminal Schwann cells at the human neuromuscular junction. Brain Commun. 2021, 3, fcab081. [CrossRef] [PubMed]

48. Martineau, É.; Arbour, D.; Vallée, J.; Robitaille, R. Properties of Glial Cell at the Neuromuscular Junction Are Incompatible with Synaptic Repair in the SOD1G37R ALS Mouse Model. J. Neurosci. 2020, 40, 7759-7777. [CrossRef] [PubMed]

49. Arbour, D.; Vande Velde, C.; Robitaille, R. New perspectives on amyotrophic lateral sclerosis: The role of glial cells at the neuromuscular junction. J. Physiol. 2017, 595, 647-661. [CrossRef] [PubMed]

50. Carrasco, D.I.; Seburn, K.L.; Pinter, M.J. Altered terminal Schwann cell morphology precedes denervation in SOD1 mice. Exp. Neurol. 2016, 275, 172-181. [CrossRef] [PubMed]

51. Bruneteau, G.; Bauché, S.; Gonzalez de Aguilar, J.L.; Brochier, G.; Mandjee, N.; Tanguy, M.-L.; Hussain, G.; Behin, A.; Khiami, F.; Sariali, E.; et al. Endplate denervation correlates with Nogo-A muscle expression in amyotrophic lateral sclerosis patients. Ann. Clin. Transl. Neurol. 2015, 2, 362-372. [CrossRef] [PubMed]

52. Liu, J.-X.; Brännström, T.; Andersen, P.M.; Pedrosa-Domellöf, F. Distinct changes in synaptic protein composition at neuromuscular junctions of extraocular muscles versus limb muscles of ALS donors. PLoS ONE 2013, 8, e57473. [CrossRef] [PubMed]

53. Alhindi, A.; Boehm, I.; Chaytow, H. Small junction, big problems: Neuromuscular junction pathology in mouse models of amyotrophic lateral sclerosis (ALS). J. Anat. 2021, 1-19. [CrossRef] [PubMed]

54. Benatar, M. Lost in translation: Treatment trials in the SOD1 mouse and in human ALS. Neurobiol. Dis. 2007, 26, 1-13. [CrossRef] [PubMed]

55. Kastriti, M.E.; Adameyko, I. Specification, plasticity and evolutionary origin of peripheral glial cells. Curr. Opin. Neurobiol. 2017, 47, 196-202. [CrossRef] [PubMed]

56. Cimadamore, F.; Fishwick, K.; Giusto, E.; Gnedeva, K.; Cattarossi, G.; Miller, A.; Pluchino, S.; Brill, L.M.; Bronner-Fraser, M.; Terskikh, A.V. Human ESC-derived neural crest model reveals a key role for SOX2 in sensory neurogenesis. Cell Stem Cell 2011, 8, 538-551. [CrossRef] [PubMed]

57. Menendez, L.; Yatskievych, T.A.; Antin, P.B.; Dalton, S. Wnt signaling and a Smad pathway blockade direct the differentiation of human pluripotent stem cells to multipotent neural crest cells. Proc. Natl. Acad. Sci. USA 2011, 108, 19240-19245. [CrossRef] [PubMed]

58. Ma, M.-S.; Boddeke, E.; Copray, S. Pluripotent stem cells for Schwann cell engineering. Stem Cell Rev. Rep. 2015, 11, 205-218. [CrossRef] [PubMed]

59. Francis, G.L. Albumin and mammalian cell culture: Implications for biotechnology applications. Cytotechnology 2010, 62, 1-16. [CrossRef] [PubMed]

60. Li, W.; Sun, W.; Zhang, Y.; Wei, W.; Ambasudhan, R.; Xia, P.; Talantova, M.; Lin, T.; Kim, J.; Wang, X.; et al. Rapid induction and long-term self-renewal of primitive neural precursors from human embryonic stem cells by small molecule inhibitors. Proc. Natl. Acad. Sci. USA 2011, 108, 8299-8304. [CrossRef] [PubMed]

61. Leung, A.W.; Murdoch, B.; Salem, A.F.; Prasad, M.S.; Gomez, G.A.; García-Castro, M.I. WNT/ $\beta$-catenin signaling mediates human neural crest induction via a pre-neural border intermediate. Development 2016, 143, 398-410. [CrossRef] [PubMed]

62. Huang, M.; Miller, M.L.; McHenry, L.K.; Zheng, T.; Zhen, Q.; Ilkhanizadeh, S.; Conklin, B.R.; Bronner, M.E.; Weiss, W.A. Generating trunk neural crest from human pluripotent stem cells. Sci. Rep. 2016, 6, 19727. [CrossRef]

63. Villanueva, S.; Glavic, A.; Ruiz, P.; Mayor, R. Posteriorization by FGF, Wnt, and retinoic acid is required for neural crest induction. Dev. Biol. 2002, 241, 289-301. [CrossRef]

64. Kitada, M.; Murakami, T.; Wakao, S.; Li, G.; Dezawa, M. Direct conversion of adult human skin fibroblasts into functional Schwann cells that achieve robust recovery of the severed peripheral nerve in rats. Glia 2019, 67, 950-966. [CrossRef]

65. Gao, S.; Zheng, Y.; Cai, Q.; Wu, X.; Yao, W.; Wang, J. Different methods for inducing adipose-derived stem cells to differentiate into Schwann-like cells. Arch. Med. Sci. 2015, 11, 886-892. [CrossRef] [PubMed]

66. Dezawa, M.; Takahashi, I.; Esaki, M.; Takano, M.; Sawada, H. Sciatic nerve regeneration in rats induced by transplantation of in vitro differentiated bone-marrow stromal cells. Eur. J. Neurosci. 2001, 14, 1771-1776. [CrossRef] [PubMed]

67. Latasa, M.-J.; Cosgaya, J.M. Regulation of Retinoid Receptors by Retinoic Acid and Axonal Contact in Schwann Cells. PLoS ONE 2011, 6, e17023. [CrossRef] [PubMed]

68. Huff, T.C.; Sant, D.W.; Camarena, V.; van Booven, D.; Andrade, N.S.; Mustafi, S.; Monje, P.V.; Wang, G. Vitamin C regulates Schwann cell myelination by promoting DNA demethylation of pro-myelinating genes. J. Neurochem. 2021, 157, 1759-1773. [CrossRef] [PubMed]

69. Eldridge, C.F.; Bunge, M.B.; Bunge, R.P.; Wood, P.M. Differentiation of axon-related Schwann cells in vitro. I. Ascorbic acid regulates basal lamina assembly and myelin formation. J. Cell Biol. 1987, 105, 1023-1034. [CrossRef] [PubMed]

70. Park, S.E.; Ahn, J.; Jeong, H.-E.; Youn, I.; Huh, D.; Chung, S. A three-dimensional in vitro model of the peripheral nervous system. NPG Asia Mater 2021, 13, 1-11. [CrossRef] 
71. Bacallao, K.; Monje, P.V. Requirement of cAMP signaling for Schwann cell differentiation restricts the onset of myelination. PLoS ONE 2015, 10, e0116948. [CrossRef] [PubMed]

72. Callizot, N.; Combes, M.; Steinschneider, R.; Poindron, P. A new long term in vitro model of myelination. Exp. Cell Res. 2011, 317, 2374-2383. [CrossRef] [PubMed]

73. Latasa, M.-J.; Ituero, M.; Moran-Gonzalez, A.; Aranda, A.; Cosgaya, J.M. Retinoic acid regulates myelin formation in the peripheral nervous system. Glia 2010, 58, 1451-1464. [CrossRef] [PubMed]

74. Latasa, M.-J.; Jiménez-Lara, A.M.; Cosgaya, J.M. Retinoic acid regulates Schwann cell migration via NEDD9 induction by transcriptional and post-translational mechanisms. Biochim. Biophys. Acta 2016, 1863, 1510-1518. [CrossRef] [PubMed]

75. Chevrel, G.; Hohlfeld, R.; Sendtner, M. The role of neurotrophins in muscle under physiological and pathological conditions Muscle Nerve 2006, 33, 462-476. [CrossRef] [PubMed]

76. Sakuma, K.; Yamaguchi, A. The recent understanding of the neurotrophin's role in skeletal muscle adaptation. J. Biomed. Biotechnol. 2011, 2011, 201696. [CrossRef]

77. Gonzalez, M.; Ruggiero, F.P.; Chang, Q.; Shi, Y.-J.; Rich, M.M.; Kraner, S.; Balice-Gordon, R.J. Disruption of TrkB-Mediated Signaling Induces Disassembly of Postsynaptic Receptor Clusters at Neuromuscular Junctions. Neuron 1999, 24, 567-583. [CrossRef]

78. Griesbeck, O.; Parsadanian, A.S.; Sendtner, M.; Thoenen, H. Expression of neurotrophins in skeletal muscle: Quantitative comparison and significance for motoneuron survival and maintenance of function. J. Neurosci. Res. 1995, 42, 21-33. [CrossRef] [PubMed]

79. Klein, R.; Silos-Santiago, I.; Smeyne, R.J.; Lira, S.A.; Brambilla, R.; Bryant, S.; Zhang, L.; Snider, W.D.; Barbacid, M. Disruption of the neurotrophin-3 receptor gene trkC eliminates la muscle afferents and results in abnormal movements. Nature 1994, 368, 249-251. [CrossRef]

80. Ernfors, P.; Lee, K.-F.; Kucera, J.; Jaenisch, R. Lack of neurotrophin-3 leads to deficiencies in the peripheral nervous system and loss of limb proprioceptive afferents. Cell 1994, 77, 503-512. [CrossRef]

81. Colombo, E.; Bedogni, F.; Lorenzetti, I.; Landsberger, N.; Previtali, S.C.; Farina, C. Autocrine and immune cell-derived BDNF in human skeletal muscle: Implications for myogenesis and tissue regeneration. J. Pathol. 2013, 231, 190-198. [CrossRef]

82. Clow, C.; Jasmin, B.J. Brain-derived neurotrophic factor regulates satellite cell differentiation and skeltal muscle regeneration. MBoC 2010, 21, 2182-2190. [CrossRef]

83. Kulakowski, S.A.; Parker, S.D.; Personius, K.E. Reduced TrkB expression results in precocious age-like changes in neuromuscular structure, neurotransmission, and muscle function. J. Appl. Physiol. 2011, 111, 844-852. [CrossRef] [PubMed]

84. Delezie, J.; Weihrauch, M.; Maier, G.; Tejero, R.; Ham, D.J.; Gill, J.F.; Karrer-Cardel, B.; Rüegg, M.A.; Tabares, L.; Handschin, C. BDNF is a mediator of glycolytic fiber-type specification in mouse skeletal muscle. Proc. Natl. Acad. Sci. USA 2019, 116, 16111-16120. [CrossRef] [PubMed]

85. Ruberti, F.; Capsoni, S.; Comparini, A.; Di Daniel, E.; Franzot, J.; Gonfloni, S.; Rossi, G.; Berardi, N.; Cattaneo, A. Phenotypic Knockout of Nerve Growth Factor in Adult Transgenic Mice Reveals Severe Deficits in Basal Forebrain Cholinergic Neurons, Cell Death in the Spleen, and Skeletal Muscle Dystrophy. J. Neurosci. 2000, 20, 2589-2601. [CrossRef]

86. Capsoni, S.; Ruberti, F.; Di Daniel, E.; Cattaneo, A. Muscular dystrophy in adult and aged anti-NGF transgenic mice resembles an inclusion body myopathy. J. Neurosci. Res. 2000, 59, 553-560. [CrossRef]

87. Wu, H.; Xiong, W.C.; Mei, L. To build a synapse: Signaling pathways in neuromuscular junction assembly. Development 2010, 137, 1017-1033. [CrossRef] [PubMed]

88. Ruegg, M.A.; Bixby, J.L. Agrin orchestrates synaptic differentiation at the vertebrate neuromuscular junction. Trends Neurosci. 1998, 21, 22-27. [CrossRef]

89. Luo, S.; Zhang, B.; Dong, X.; Tao, Y.; Ting, A.; Zhou, Z.; Meixiong, J.; Luo, J.; Chiu, F.C.A.; Xiong, W.C.; et al. HSP90 beta regulates rapsyn turnover and subsequent AChR cluster formation and maintenance. Neuron 2008, 60, 97-110. [CrossRef]

90. Bruneau, E.; Akaaboune, M. The dynamics of the rapsyn scaffolding protein at individual acetylcholine receptor clusters. J. Biol. Chem. 2007, 282, 9932-9940. [CrossRef] [PubMed]

91. Moransard, M.; Borges, L.S.; Willmann, R.; Marangi, P.A.; Brenner, H.R.; Ferns, M.J.; Fuhrer, C. Agrin regulates rapsyn interaction with surface acetylcholine receptors, and this underlies cytoskeletal anchoring and clustering. J. Biol. Chem. 2003, 278, 7350-7359. [CrossRef] [PubMed]

92. Mittaud, P.; Marangi, P.A.; Erb-Vögtli, S.; Fuhrer, C. Agrin-induced activation of acetylcholine receptor-bound Src family kinases requires Rapsyn and correlates with acetylcholine receptor clustering. J. Biol. Chem. 2001, 276, 14505-14513. [CrossRef]

93. Yang, J.-F.; Cao, G.; Koirala, S.; Reddy, L.V.; Ko, C.-P. Schwann Cells Express Active Agrin and Enhance Aggregation of Acetylcholine Receptors on Muscle Fibers. J. Neurosci. Off. J. Soc. Neurosci. 2001, 21, 9572-9584. [CrossRef]

94. Castro, R.; Taetzsch, T.; Vaughan, S.K.; Godbe, K.; Chappell, J.; Settlage, R.E.; Valdez, G. Specific labeling of synaptic schwann cells reveals unique cellular and molecular features. Elife 2020, 9, e56935. [CrossRef]

95. Ferns, M.J.; Campanelli, J.T.; Hoch, W.; Scheller, R.H.; Hall, Z. The ability of agrin to cluster AChRs depends on alternative splicing and on cell surface proteoglycans. Neuron 1993, 11, 491-502. [CrossRef]

96. Jung, J.H.; Smith, I.; Mikesh, M. Terminal Schwann cell and vacant site mediated synapse elimination at developing neuromuscular junctions. Sci. Rep. 2019, 9, 18594. [CrossRef] [PubMed] 
97. Lee, Y.I.; Li, Y.; Mikesh, M.; Smith, I.; Nave, K.-A.; Schwab, M.H.; Thompson, W.J. Neuregulin1 displayed on motor axons regulates terminal Schwann cell-mediated synapse elimination at developing neuromuscular junctions. Proc. Natl. Acad. Sci. USA 2016, 113, E479-E487. [CrossRef] [PubMed]

98. Zelada, D.; Bermedo-García, F.; Collao, N.; Henríquez, J.P. Motor function recovery: Deciphering a regenerative niche at the neuromuscular synapse. Biol. Rev. Camb. Philos. Soc. 2021, 96, 752-766. [CrossRef] [PubMed]

99. VanSaun, M.; Humburg, B.C.; Arnett, M.G.; Pence, M.; Werle, M.J. Activation of Matrix Metalloproteinase-3 is altered at the frog neuromuscular junction following changes in synaptic activity. Dev. Neurobiol. 2007, 67, 1488-1497. [CrossRef] [PubMed]

100. VanSaun, M.; Werle, M.J. Matrix metalloproteinase-3 removes agrin from synaptic basal lamina. J. Neurobiol. 2000, 43, 140-149. [CrossRef]

101. Chao, T.; Frump, D.; Lin, M.; Caiozzo, V.J.; Mozaffar, T.; Steward, O.; Gupta, R. Matrix metalloproteinase 3 deletion preserves denervated motor endplates after traumatic nerve injury. Ann. Neurol. 2013, 73, 210-223. [CrossRef]

102. VanSaun, M.; Herrera, A.A.; Werle, M.J. Structural alterations at the neuromuscular junctions of matrix metalloproteinase 3 null mutant mice. J. Neurocytol. 2003, 32, 1129-1142. [CrossRef]

103. Peng, H.B.; Yang, J.-F.; Dai, Z.; Lee, C.W.; Hung, H.W.; Feng, Z.H.; Ko, C.-P. Differential effects of neurotrophins and schwann cell-derived signals on neuronal survival/growth and synaptogenesis. J. Neurosci. Off. J. Soc. Neurosci. 2003, 23, 5050-5060. [CrossRef]

104. Wells, D.G.; McKechnie, B.A.; Kelkar, S.; Fallon, J.R. Neurotrophins regulate agrin-induced postsynaptic differentiation. Proc. Natl. Acad. Sci. USA 1999, 96, 1112-1117. [CrossRef] [PubMed]

105. Lin, W.; Dominguez, B.; Yang, J.; Aryal, P.; Brandon, E.P.; Gage, F.H.; Lee, K.-F. Neurotransmitter acetylcholine negatively regulates neuromuscular synapse formation by a Cdk5-dependent mechanism. Neuron 2005, 46, 569-579. [CrossRef] [PubMed]

106. Misgeld, T.; Burgess, R.W.; Lewis, R.M.; Cunningham, J.M.; Lichtman, J.W.; Sanes, J.R. Roles of Neurotransmitter in Synapse Formation. Neuron 2002, 36, 635-648. [CrossRef]

107. Rimington, R.P.; Fleming, J.W.; Capel, A.J.; Wheeler, P.C.; Lewis, M.P. Bioengineered model of the human motor unit with physiologically functional neuromuscular junctions. Sci. Rep. 2021, 11, 11695. [CrossRef] [PubMed]

108. Guo, X.; Badu-Mensah, A.; Thomas, M.C.; McAleer, C.W.; Hickman, J.J. Characterization of Functional Human Skeletal Myotubes and Neuromuscular Junction Derived-From the Same Induced Pluripotent Stem Cell Source. Bioengineering 2020, 7, 133. [CrossRef] [PubMed]

109. Uzel, S.G.M.; Platt, R.J.; Subramanian, V.; Pearl, T.M.; Rowlands, C.J.; Chan, V.; Boyer, L.A.; So, P.T.C.; Kamm, R.D. Microfluidic device for the formation of optically excitable, three-dimensional, compartmentalized motor units. Sci. Adv. 2016, 2, 8. [CrossRef] [PubMed]

110. Yamamoto, K.; Yamaoka, N.; Imaizumi, Y.; Nagashima, T.; Furutani, T.; Ito, T.; Okada, Y.; Honda, H.; Shimizu, K. Development of a human neuromuscular tissue-on-a-chip model on a 24-well-plate-format compartmentalized microfluidic device. Lab A Chip 2021, 21, 1897-1907. [CrossRef]

111. Afshar Bakooshli, M.; Lippmann, E.S.; Mulcahy, B.; Iyer, N.; Nguyen, C.T.; Tung, K.; Stewart, B.A.; van den Dorpel, H.; Fuehrmann, T.; Shoichet, M.; et al. A 3D culture model of innervated human skeletal muscle enables studies of the adult neuromuscular junction. Elife 2019, 8, e44530. [CrossRef] [PubMed]

112. Steinbeck, J.A.; Jaiswal, M.K.; Calder, E.L.; Kishinevsky, S.; Weishaupt, A.; Toyka, K.V.; Goldstein, P.A.; Studer, L. Functional Connectivity under Optogenetic Control Allows Modeling of Human Neuromuscular Disease. Cell Stem Cell 2016, 18, 134-143. [CrossRef] [PubMed]

113. Osaki, T.; Uzel, S.G.M.; Kamm, R.D. Microphysiological 3D model of amyotrophic lateral sclerosis (ALS) from human iPS-derived muscle cells and optogenetic motor neurons. Sci. Adv. 2018, 4, eaat5847. [CrossRef]

114. Smith, A.; Long, C.J.; Pirozzi, K.; Hickman, J.J. A functional system for high-content screening of neuromuscular junctions in vitro. Technology 2013, 1, 37-48. [CrossRef]

115. Santhanam, N.; Kumanchik, L.; Guo, X.; Sommerhage, F.; Cai, Y.; Jackson, M.; Martin, C.; Saad, G.; McAleer, C.W.; Wang, Y.; et al. Stem cell derived phenotypic human neuromuscular junction model for dose response evaluation of therapeutics. Biomaterials 2018, 166, 64-78. [CrossRef] [PubMed]

116. Osaki, T.; Uzel, S.G.M.; Kamm, R.D. On-chip 3D neuromuscular model for drug screening and precision medicine in neuromuscular disease. Nat. Protoc. 2020, 15, 421-449. [CrossRef]

117. Wang, P.-Y.; Thissen, H.; Tsai, W.-B. The roles of RGD and grooved topography in the adhesion, morphology, and differentiation of C2C12 skeletal myoblasts. Biotechnol. Bioeng. 2012, 109, 2104-2115. [CrossRef] [PubMed]

118. Thomson, S.R.; Wishart, T.M.; Patani, R.; Chandran, S.; Gillingwater, T.H. Using induced pluripotent stem cells (iPSC) to model human neuromuscular connectivity: Promise or reality? J. Anat. 2012, 220, 122-130. [CrossRef] [PubMed]

119. Negro, S.; Bergamin, E.; Rodella, U.; Duregotti, E.; Scorzeto, M.; Jalink, K.; Montecucco, C.; Rigoni, M. ATP Released by Injured Neurons Activates Schwann Cells. Front. Cell. Neurosci. 2016, 10, 134. [CrossRef] [PubMed] 